\title{
Working
}

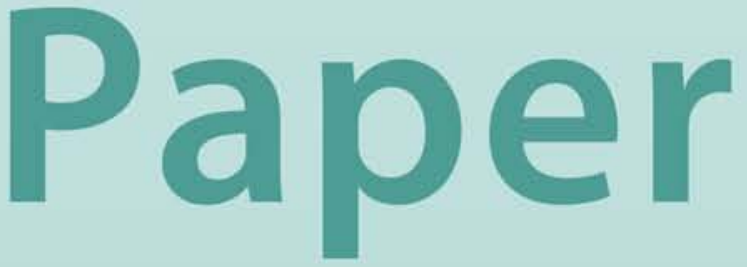




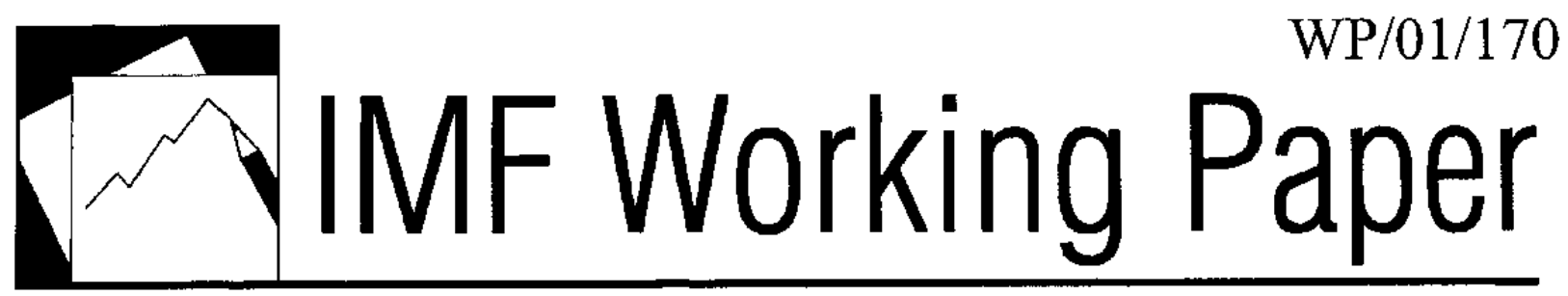

Post-Crisis Exchange Rate Policy in Five Asian Countries:

Filling in the "Hollow Middle"?

Leonardo Hernández and Peter Montiel 


\title{
IMF Working Paper
}

\author{
IMF Institute
}

\section{Post-Crisis Exchange Rate Policy in Five Asian Countries: Filling in the "Hollow Middle"?}

\author{
Prepared by Leonardo Hernández and Peter Montiel ${ }^{1}$ \\ Authorized for distribution by Reza Vaez-Zadeh
}

November 2001

\begin{abstract}
The views expressed in this Working Paper are those of the author(s) and do not necessarily represent those of the IMF or IMF policy. Working Papers describe research in progress by the author(s) and are published to elicit comments and to further debate.
\end{abstract}

Following the 1997-98 financial turmoil, crisis countries in Asia moved toward either floating or fixed exchange rate systems, reinforcing the bipolar view of exchange rate regimes and the "hollow middle" hypothesis. But some academics have claimed that the crisis countries' policies have been similar in the post- and pre-crisis periods. This paper analyzes the evidence and concludes that, except for Malaysia, which adopted a hard peg and imposed capital controls, the other crisis countries are floating more than before, though less than "real" floaters do. Further, the crisis countries' policies during the post-crisis period can be justified on second-best arguments.

JEL Classification Numbers:F32; E65

Keywords: exchange rate policy

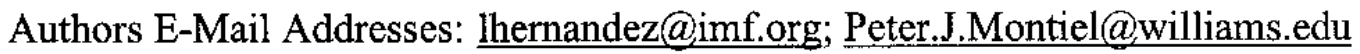

\footnotetext{
${ }^{1}$ International Monetary Fund and Williams College, respectively. A preliminary version of this paper was presented at the IMF Institute high-levcl seminar Exchange Rate Regimes: Hard Peg or Free Floating?, Washington, March 19-20, 2001, and at ESAM 2001, Auckland, July 6-8. We are grateful to Jahangir Aziz, Raymond Brooks, Qaizar Hussain, Gunnar Jonsson, Mohsin Khan, Kalpana Kochhar, Hong Liang, Olin Liu, and Reza Vaez-Zadeh for providing useful comments on an earlier draft.
} 


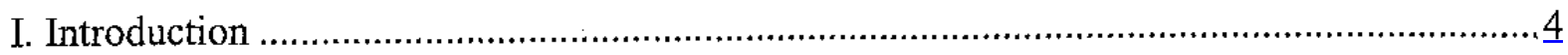

II. Post-Crisis Exchange Rate Policies in the Asian Crisis Countries: De Jure ........................

III. Identifying Exchange Rate Regimes De Facto ........................................................

A. Exchange Rate Volatility ...........................................................................

B. Foreign Exchange Reserve Volatility ..............................................................

C. Interest Rate Volatility ...........................................................................11

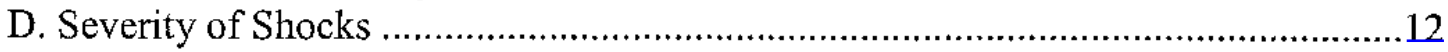

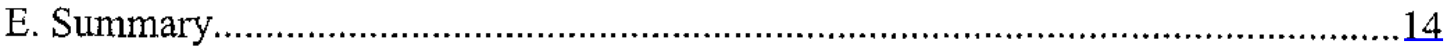

IV. Objectives of Post-Crisis Exchange Rate Policy ..................................................16

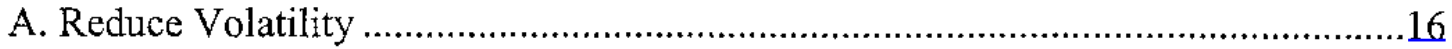

B. Stabilization of the Nominal Effective Exchange Rate ....................................17

C. Stabilization of the Real Effective Exchange Rate ..........................................20

D. Smoothing the Pace of Depreciation...............................................................21

E. Smoothing the Pace of Appreciation ..........................................................22

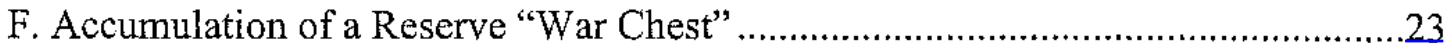

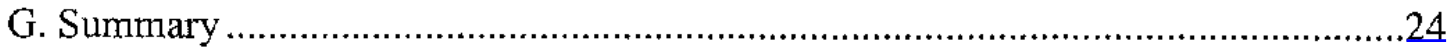

V. An Evaluation: Exchange Rate Policy and Post-Crisis Economics ................................25

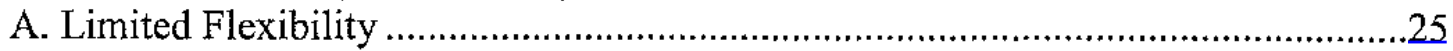

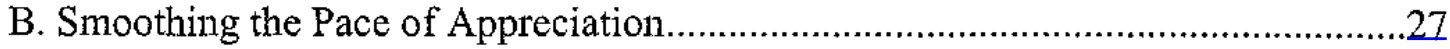

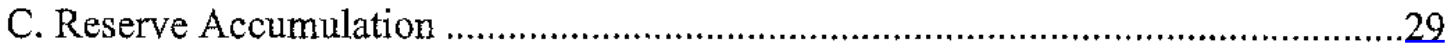

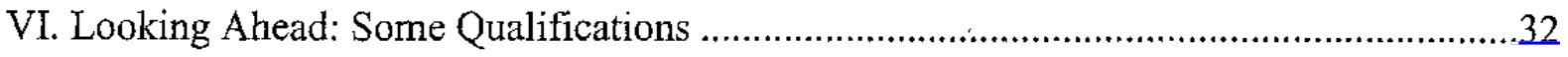

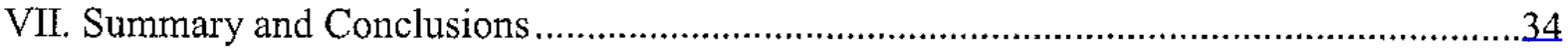

Text Tables

1. Official Exchange Rate Regimes in the Asian Crisis Countries.....................................6

2. Monthly Nominal Exchange Rate Volatility in Five Asian Crisis Countries ......................9

3. Monthly Reserve Volatility in Five Asian Crisis Countries ........................................10

4. Monthly Interest Rate Volatility in Five Asian Crisis Countries....................................12

5. Exchange Market Volatility in the Asian Crisis Countries..........................................13

6. Volatility Ratios in Five Asian Crisis Countries.....................................................15

7. Bivariate Correlations Among Nominal Exchange Rates in Five Asian Countries ...........20

8. Bivariate Correlations Among the Real Exchange Rate and its Components in Five Asian Countries

9. Real GDP and Volume of Exports: Growth During Post-Crisis Recovery in Eight Crisis Countries 
Figures

1. Bilateral Exchange Rates for Five Asian Countries ....................................................

2. Post-Crisis Reserve Accumulation in the Five Crisis Countries ...................................18

3. Reserve Stocks in Non-Crisis and Crisis Countries, 1996..............................................

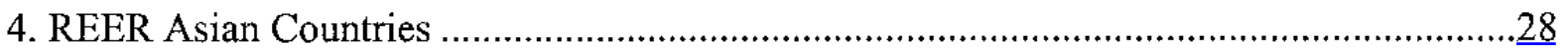

5. Post-Crisis Exchange Market Pressure in the Five Crisis Economies ..............................

Appendix

1. Asian Crisis Countries in McKinnon ..........................................................................

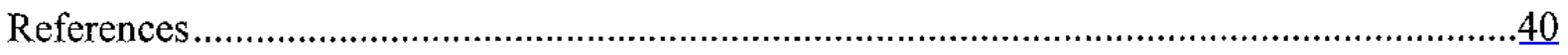




\section{INTRODUCTION}

The severe financial crises experienced over the past decade by many emerging market economies have been attributed to a variety of causes of which an important common one is the attempts by the crisis countries to maintain exchange rate regimes ("soft" pegs) that were no longer viable in light of their greatly enhanced integration with international capital markets. In the context of such enhanced integration, it has been argued, only the polar extremes of floating exchange rates or fixed exchange rates, supported by very strong commitment mechanisms ("hard" pegs), can be sustained for extended periods. In other words, the recurrent crises of recent years reflect the inevitable breakdown of intermediate regimes.

Among the crises of the 1990s, the Asian financial crisis of 1997-98 has certainly played a key role in generating the perception of a vanishing middle ground for exchange rate regimes in developing countries, a doctrine that has come to be known as the "hollow middle." The macroeconomic performance of the Asian economies that later succumbed to currency and banking crises (Indonesia, Korea, Malaysia, the Philippines, and Thailand) had previously been hailed as an economic miracle, and active management of the exchange rate in pursuit of the competitiveness objective had often been credited with making an important contribution to their "miraculous" macroeconomic performance. The crisis forced all of these countries to abandon their de facto exchange rate pegs, and the subsequent floats of their currencies were associated with very sharp fluctuations in their values. Thus, if even these economies with such exceptional macroeconomic fundamentals proved unable to sustain a policy of active exchange rate management in a more financially integrated world during the $1990 \mathrm{~s}$, prospects would appear to be bleak for other developing countries to do so.

More recently, doubts have arisen about post-crisis exchange rate policies in the Asian crisis countries themselves. Several observers have noted that in the wake of their crises, several of these countries may be reverting to exchange rate practices similar to those of the pre-crisis period, in the sense that their authorities have sought to stabilize the values of their currencies against the U.S. dollar without adopting any of the strong commitment mechanisms that would be called for under the doctrine of the "hollow middle." The worry among such observers is that, in view of the vanishing scope for 'soft' peg arrangements under current international financial conditions, resuming such practices in the former crisis countries may make them vulnerable to a repetition of the events of $1997-98 .^{2}$ The implied policy advice is that these countries themselves should opt for one of the extreme currency arrangements that their own past experience (and that of others) suggests as the only viable options as long as they remain highly integrated with world capital markets.

This paper addresses two issues raised by this recent experience. Its narrower objective is to identify and evaluate post-crisis exchange rate policy in five of the countries that suffered most severely from the Asian financial crisis. For this purpose, we seek to determine the extent

${ }^{2}$ See, for example, Mussa and others (2000). 
to which these countries have indeed reverted to their pre-crisis exchange rate practices, to characterize the exchange rate policies they are currently pursuing, and to evaluate the appropriateness of such policies in light of both contemporary international financial conditions as well as of the post-crisis circumstances of those economies. The broader objective is to draw lessons from that experience for the doctrine of the "hollow middle" for exchange rate policies.

The paper is organized as follows. In Sections II and III, we attempt to identify the exchange rate regimes that have prevailed in five former crisis countries-Indonesia, Korea, Malaysia, the Philippines, and Thailand - during the post-crisis period. To eliminate the period of most severe instability associated with the crisis, we define the post-crisis as $1999-2000 .^{3}$ Having characterized the exchange rate regimes, we turn in Section IV to a consideration of the possible objectives that may have been driving the formulation of post-crisis exchange rate policies in the former crisis countries. Our next task, undertaken in Section V, is to evaluate the objectives and conduct of exchange rate policy in light of the post-crisis circumstances faced by these five economies. Section VI takes up some considerations that can be expected to influence longer term exchange rate policies in these economies. In our concluding section we summarize our findings and attempt to draw lessons from the post-crisis experience of the Asian crisis countries for exchange rate management in other developing countries.

\section{Post-Crisis Exchange Rate Policies in the Asian Crisis Countries: De JURE}

In evaluating the post-crisis exchange rate policies of the Asian crisis countries, the first issue we face is identifying the exchange rate policies that each of these countries pursued during the post-crisis period. In this section and the next, we address this basic question. Our main concerns are two: first, to identify how exchange rate policy has changed in each of these countries from the pre-crisis to the post-crisis period; second, to place their post-crisis exchange rate policies in an international context. In other words, given a continuum from hard pegs to cleanly floating exchange rates, we want to identify the direction in which each of these countries has moved along this continuum as well as where they stand on this scale in their postcrisis conduct of exchange rate policies.

The official IMF classifications of exchange rate regimes for our five countries before and after the Asian financial crisis are reported in Table 1. According to this classification, at least three of the five countries in our group (Indonesia, Korea, and Thailand) underwent a transformation in their officially-declared exchange rate regimes in the direction of greater flexibility as a result of the crisis, while one-Malaysia-moved in the opposite direction. Only the Philippines retained its pre-crisis exchange regime classification.

\footnotetext{
${ }^{3}$ More precisely, we have defined the post-crisis period as beginning in January 1999, and have defined the pre-crisis period as a period of equal length ( 24 months) ending in June 1997.
} 
Table 1. Official Exchange Rate Regimes in the Asian Crisis Countries

$\begin{array}{lll}\text { Indonesia } & \text { November 1978-June 1997 } & \text { Managed Floating } \\ & \text { July 1997-December 2000 } & \text { Independently Floating } \\ \text { Korea } & \text { March 1980-October 1997 } & \text { Managed Floating } \\ & \text { November 1997-December 2000 } & \text { Independently Floating } \\ \text { Malaysia } & \text { January 1986-February 1990 } & \text { Limited Flexibility } \\ & \text { March 1990-November 1992 } & \text { Fixed } \\ & \text { December 1992-September 1998 } & \text { Managed Floating } \\ & \text { Scptember 1998-December 2000 } & \text { Pegged Arrangement } \\ \text { Philippines } & \text { January 1988-December 2000 } & \text { Independently Floating } \\ \text { Thailand } & \text { January 1970-June 1997 } & \text { Fixed } \\ & \text { July 1997-December 2000 } & \text { Independently Floating }\end{array}$

Source: IMF, Exchange Arrangements and Exchange Restrictions, several issues.

But there are at least two reasons to question whether these official classifications adequately capture how exchange rate policy has evolved in these countries from the pre- to the post-crisis period.

First, with the exception of Thailand, which described itself as pegged to an undisclosed currency basket, none of these countries maintained an exchange rate regime officially classified as "fixed" prior to the crisis. The classification of the remaining pre-crisis regimes as "floating" in some fashion seems to run counter to the conventional wisdom about the role of exchange rate pegs in determining vulnerability to crisis. To the extent that these countries were defending an exchange rate peg prior to the crisis, therefore, their actions were at odds with their officially declared exchange rate regimes.

Second, there has been a growing perception among knowledgeable observers that little may have changed with respect to exchange rate policy in these countries after the crisis. Calvo and Reinhart (2000a), for example, conclude about our countries: "Indeed, once financial markets settled and capital flowed back into Asia, their currencies are fluctuating much the way they did prior to the crisis - that is to say, they are not fluctuating at all." (p. 27). Similarly, McKinnon (2000), states: "In the year 2000, both the crisis and non-crisis countries of East Asia (with Japan remaining the important exception) have returned to formal or informal dollar pegging, which is statistically indistinguishable from what they were doing before the crisis." (p. 9). 
The difference between the de jure and de facto exchange rate regimes in the crisis countries before the crisis, ${ }^{4}$ together with the conclusions drawn by knowledgeable observers about actual post-crisis exchange rate policies in these countries, raise the possibility that the gap between de jure and de facto exchange rate regimes that existed in the Asian crisis countries before the crisis may have reasserted itself after the crisis. The identification of post-crisis exchange rate policies in these countries is thus an empirical issue.

\section{IDENTIFYING EXCHANGE RATE REgIMES DE FACTO}

The acknowledged gap between de jure and de facto exchange rate policies in many countries has recently given rise to a new literature identifying how exchange rate policies have actually been conducted in emerging markets, based on observed outcomes for exchange rates, foreign exchange reserves, and domestic interest rates. Of course, the polar opposite cases of bilateral pegs with very narrow bands, on the one hand, and clean floats, on the other, are in principle easy to identify. A fixed bilateral peg would exhibit no exchange rate variation outside a very narrow band (conventionally taken as $+/-2.25$ percent), while a clean float would exhibit no foreign-exchange market intervention-i.e., no variation in an appropriately-measured stock of foreign exchange reserves. ${ }^{5}$

Beyond these extreme exchange rate arrangements, what is of interest is the degree of commitment to a "soft peg." The preceding observation suggests that it may be possible to assess this degree of commitment on the basis of the observed volatilities of financial variables such as exchange rates and stocks of foreign exchange reserves. This degree of commitment could then be gauged on the basis of cross-country comparisons of such volatilities, or by comparisons of the behavior of such variables in the same country over different periods of time.

\section{A. Exchange Rate Volatility}

Figure 1 shows the bilateral exchange rate against the U.S. dollar for the five countries in our group, both before and after the crisis. It is evident that Malaysia and Indonesia are outliers in our sample. Malaysia has announced and implemented a fixed exchange rate in the post-crisis period, while the exchange rate for the Indonesia rupiah has quite clearly been significantly more variable in the post- than in the pre-crisis period. ${ }^{6}$ For the other countries the visual evidence suggests more variability post-crisis, but is not so clear-cut.

${ }^{4}$ On this issue see Levy-Yeyati and Sturzenegger (1999).

${ }^{5}$ An appropriately measured stock of foreign reserves should correct for the 'natural' or exogenous rate of change in reserves caused by interest earnings and valuation changes; only the remaining change in reserves (due to market intervention) captures the volatility that we are interested in.

${ }^{6}$ For a definition of the pre- and post-crisis periods see footnote 3 . 
Figure 1. Bilateral Exchange Rates for Five Asian Countries August 1995-December 2000

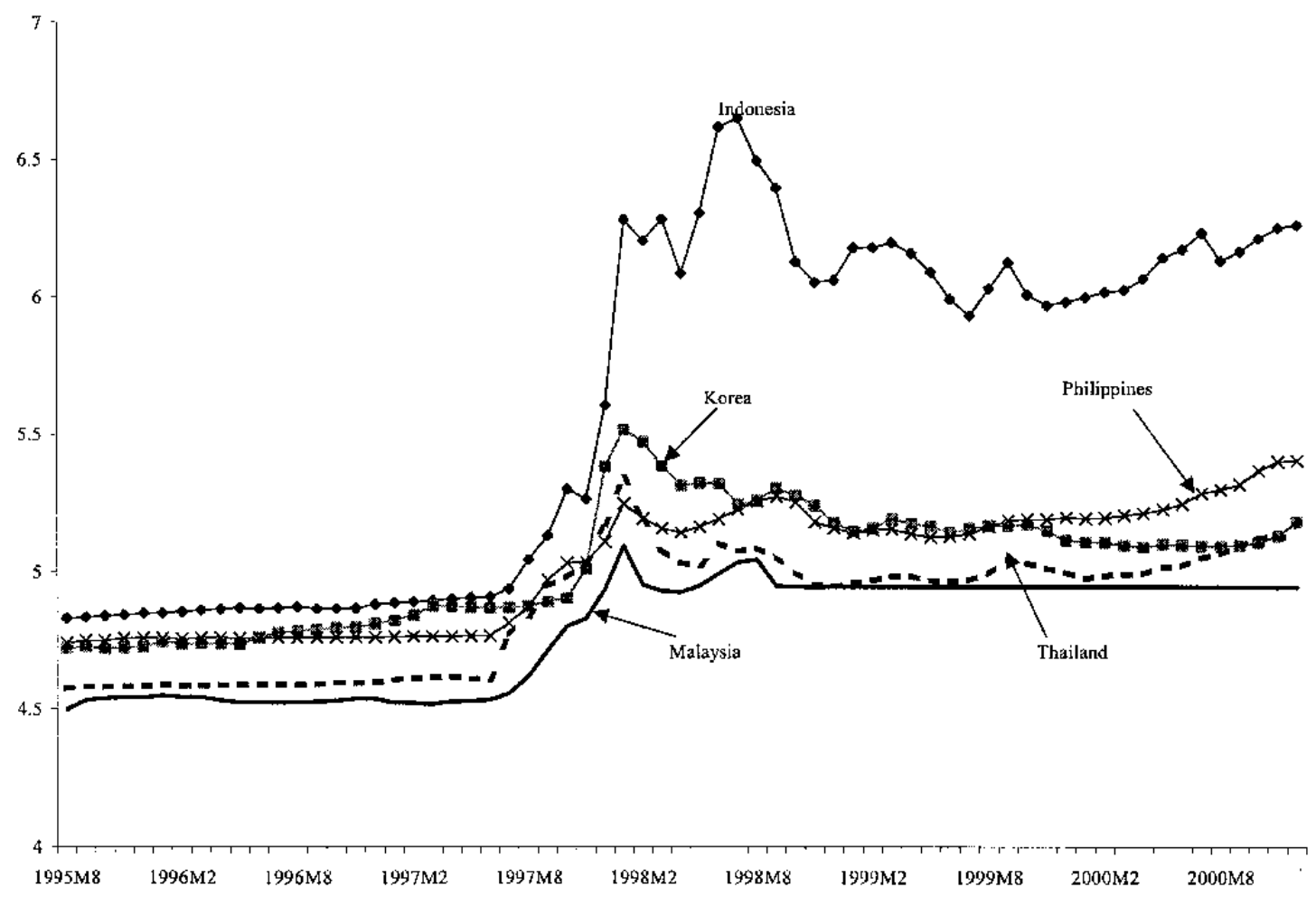

Note: the figure shows the Ln of nominal exchange rate indices (January $1990=100$ ). Source: IMF.

In Table 2, we complement this graphical evidence with some statistical measures of exchange rate volatility: the range of variation in monthly percentage exchange rate changes as well as their standard deviation. Notice from the table that, in the pre-crisis period, all five of the Asian crisis countries had much more stable exchange rates than the "clean" floaters (the U.S., Germany, and Japan), as well as Mexico, which had floated its exchange rate six months before the inception of the period we have labeled "pre-crisis." Indeed, the bilateral exchange rate against the U.S. dollar during the pre-crisis period for these five countries was more stable than that of Chile, which explicitly maintained an exchange rate band during this period. These results are consistent with the conventional wisdom that, despite the official designations of their exchange rate regimes prior to the crisis, all five of these countries actively defended an exchange rate peg.

The table confirms the sharp modifications that have taken place between the pre- and post-crisis periods in the behavior of the exchange rate in both Indonesia and Malaysia. Indeed, Indonesia's bilateral exchange rate against the U.S. dollar has been much more volatile than the bilateral rates among "clean" floaters such as the United States, Germany (the Euro during the post-crisis) and Japan. With respect to the other countries, it is obvious from the table that the volatility of monthly exchange rate changes has indeed increased after the crisis in all of them, 
though in the case of Korea, which exhibited the greatest degree of exchange rate variability before the crisis, the change is not as pronounced as for the Philippines and Thailand. The postcrisis volatility in these currencies has been comparable to that between the U.S. dollar and the Euro, as well as to that of Chile, which officially floated its currency during this period. However, for these three countries volatility remained less than that which characterized the yen-dollar rate, or the bilateral exchange rate between the Mexican peso and the U.S. dollar. This evidence suggests that there has indeed been a fundamental change in the exchange rate policies of the Asian countries pre- and post-crisis, but is consistent with the Calvo-Reinhart view that, outside of Indonesia, none of the countries that describe themselves as independently floating have become "clean" floaters.

Table 2. Monthly Nominal Exchange Rate Volatility in Five Asian Crisis Countries

\begin{tabular}{llcc}
\hline & Period & Range & Standard Deviation \\
\hline U.S. \$/DM & Pre-crisis & 0.083 & 0.024 \\
U.S.\$/Yen & Post-crisis & 0.078 & 0.021 \\
Chile & Pre-crisis & 0.147 & 0.030 \\
& Post-crisis & 0.084 & 0.028 \\
Mexico & Pre-crisis & 0.050 & 0.012 \\
& Post-crisis & 0.059 & 0.020 \\
Indonesia & Pre-crisis & 0.068 & 0.019 \\
& Post-crisis & 0.104 & 0.029 \\
Korea & Pre-crisis & 0.033 & 0.007 \\
& Post-crisis & 0.230 & 0.063 \\
Malaysia & Pre-crisis & 0.043 & 0.011 \\
\multirow{3}{*}{ Philippines } & Post-crisis & 0.066 & 0.017 \\
Thailand & Pre-crisis & 0.027 & 0.007 \\
& Post-crisis & 0.00 & 0.00 \\
& Pre-crisis & 0.012 & 0.003 \\
\hline
\end{tabular}

Source: Authors' calculations.

\section{B. Foreign Exchange Reserve Volatility}

A second indicator of exchange rate policy is the volatility in a country's foreign exchange reserves. Intervention in the foreign exchange market involves changes in the stocks of foreign reserves held by central banks, so we might expect countries that intervene less, allowing the market exchange rate to absorb the effects of shocks, to have more stable reserve stocks than those that intervene more often to stabilize the exchange rate. Table 3 shows two measures of reserve volatility for the same countries listed in Table 2 . The measures are the mean absolute monthly percentage change in reserves, and the standard deviation of monthly reserve percentage changes. As one might expect, in the pre-crisis period, the known "clean" floaters in the group (Germany and Japan) exhibited the smallest average monthly changes in 
reserves. By contrast, mean absolute reserve changes were substantially larger for all the developing countries in the table, including our five Asian crisis countries. Consistent with the results on exchange rate volatility, this suggests that, relative to the "clean" floaters, these countries permitted much less flexibility to their exchange rates during the pre-crisis period. The conclusions are exactly the same when reserve volatility is measured as the standard deviation of monthly reserve changes (column 4 in the table).

Table 3. Monthly Reserve Volatility in Five Asian Crisis Countries

\begin{tabular}{llcc}
\hline & Period & Mean Absolute Change & Standard deviation \\
\hline Germany & Pre-crisis & 1.082 & 1.325 \\
& Post-crisis & 1.225 & 1.535 \\
Japan & Pre-crisis & 1.488 & 2.469 \\
& Post-crisis & 2.193 & 2.948 \\
Mexile & Pre-crisis & 2.274 & 2.948 \\
& Post-crisis & 2.083 & 3.086 \\
Indonesia & Pre-crisis & 5.059 & 5.911 \\
& Post-crisis & 2.341 & 3.175 \\
Korea & Pre-crisis & 2.038 & 2.892 \\
& Post-crisis & 3.169 & 5.335 \\
Malaysia & Pre-crisis & 3.046 & 3.756 \\
& Post-crisis & 2.631 & 1.808 \\
Philippines & Pre-crisis & 2.118 & 2.803 \\
\multirow{2}{*}{ Thailand } & Post-crisis & 2.643 & 3.183 \\
& Pre-crisis & 3.859 & 4.479 \\
& Post-crisis & 3.458 & 4.470 \\
& Pre-crisis & 1.850 & 2.927 \\
\hline
\end{tabular}

Source: Authors' calculations.

Reserve volatility increased for the "clean" floaters in the post-crisis period, whether measured by the mean absolute change or the standard deviation of monthly changes. Among the developing comparator countries, reserve volatility showed little change in Chile, but decreased substantially in Mexico. The latter is consistent with the evidence of Table 2 suggesting an enhanced degree of exchange rate flexibility in Mexico during this period.

Among the Asian crisis countries, reserve volatility decreased noticeably in Korea and Thailand, and very slightly in the Philippines, but increased in Indonesia and Malaysia. These results are consistent with the adoption of more flexible exchange rate arrangements in the first three countries, though reserve volatility remained much higher during the post-crisis period in the Philippines than in the "clean" floaters. ${ }^{7}$ The results are also consistent with reduced exchange rate flexibility in Malaysia, which also exhibited greater reserve volatility than either

\footnotetext{
${ }^{7}$ The degree of volatility in Korea and Thailand is bracketed by that of Germany and Japan.
} 
of the "clean" floaters. In the case of Indonesia, however, volatility seems to have increased during the post-crisis period, and remains much higher than that of the "clean floaters." The clear suggestion is that the assumption of a uniform volatility of shocks, both across countries and over time, is likely to have been violated in the case of Indonesia. We will return to this below.

\section{Interest Rate Volatility}

Our final indicator of exchange rate policy in this section will rely on the volatility of interest rates. Under our implicit assumptions that shocks are uniform across countries and over time, and that shocks arise from credibility effects, countries may seek to stabilize their exchange rates by intervening in domestic securities markets rather than by buying or selling reserves. In that case, greater exchange rate flexibility would be associated with smaller domestic interest rate volatility.

In Table 4, we measure interest rate volatility by examining the range of nominal interest rates, the mean absolute monthly change in interest rates, and the standard deviation of monthly interest rate changes. The patterns in the data can be summarized as follows:

(i) In the cases of Korea and Thailand, monthly interest rate volatility decreased in the postcrisis relative to the pre-crisis period by all of our measures. As with the previous indicators, this result is consistent with a decreased commitment to exchange rate stability during the post-crisis period in both of these countries. Nonetheless, in comparison with Germany and Japan, interest rates remained more volatile in these two countries, suggesting that their commitment to exchange rate stability in the post-crisis period remained stronger than in the "pure floaters."

(ii) As we have seen previously, Malaysia adopted a fixed exchange rate in September 1998. Under our provisional assumption of uniform credibility shocks across countries, this would suggest that in defending this rate, Malaysia should have experienced an increase in interest rate volatility relative to the pre-crisis period, when the country allowed more flexibility in its exchange rate. This is the opposite of what we find in Table 4. A possible explanation is that Malaysia's capital controls may have dampened the effects of confidence shocks in the foreign exchange market. However, we saw in Table 3 that reserve volatility has actually increased in Malaysia during the post-crisis period, suggesting the alternative explanation that reduced interest rate volatility may arise from defense of the exchange rate through sterilized - rather than unsterilized-intervention in the foreign exchange market. ${ }^{8}$

${ }^{8}$ This may also be the direct result of policies introduced in September 1998 to mitigate the effect of the crisis on the corporate sector. Given that Malaysia's corporate sector relied more heavily in domestic than external borrowing, policies were aimed at introducing a more rigid intercst rate structure and bringing domestic interest rates down. This interpretation does not deny that the overall policy approach adopted in September 1998-featuring a fixed exchange rate, sclective capital controls, a 
(iii) Finally, interest rate volatility increased in the post-crisis period for both Indonesia and the Philippines, by all three of our measures. Recall that in Indonesia both exchange rate as well as reserve volatility increased sharply in the post-crisis, while in the Philippines exchange rate volatility increased and reserve volatility was little changed. The strong suggestion is that for these two countries, what we have dubbed the "post-crisis" period has not been a tranquil one in the foreign exchange market-that is, that our assumption of uniform shocks across countries and periods is not tenable in the case of Indonesia and the Philippines.

Table 4. Monthly Interest Rate Volatility in Five Asian Crisis Countries

\begin{tabular}{|c|c|c|c|c|}
\hline & Period & Range & Mean Absolute Change & Standard Deviation \\
\hline \multirow[t]{2}{*}{ Germany } & Pre-crisis & 0.53 & 0.08 & 0.12 \\
\hline & Post-crisis & 0.68 & 0.13 & 0.16 \\
\hline \multirow[t]{2}{*}{ Japan } & Pre-crisis & 0.34 & 0.03 & 0.07 \\
\hline & Post-crisis & 0.27 & 0.02 & 0.05 \\
\hline \multirow[t]{2}{*}{ Chile } & Pre-crisis & 11.94 & 2.37 & 3.08 \\
\hline & Post-crisis & 11.36 & 1.96 & 2.59 \\
\hline \multirow[t]{2}{*}{ México } & Pre-crisis & 23.52 & 4.24 & 5.23 \\
\hline & Post-crisis & 6.86 & 1.45 & 1.84 \\
\hline \multirow[t]{2}{*}{ Indonesia } & Pre-crisis & 4.97 & 0.87 & 1.21 \\
\hline & Post-crisis & 12.19 & 2.01 & 3.12 \\
\hline \multirow[t]{2}{*}{ Korea } & Pre-crisis & 4.35 & 0.79 & 1.05 \\
\hline & Post-crisis & 0.93 & 0.13 & 0.24 \\
\hline \multirow[t]{2}{*}{ Malaysia } & Pre-crisis & 5.67 & 0.53 & 0.95 \\
\hline & Post-crisis & 1.87 & 0.16 & 0.37 \\
\hline \multirow[t]{2}{*}{ Philippines } & Prc-crisis & 3.26 & 0.53 & 0.79 \\
\hline & Post-crisis & 8.58 & 0.63 & 1.48 \\
\hline \multirow[t]{2}{*}{ Thailand } & Pre-crisis & 10.89 & 2.13 & 2.58 \\
\hline & Post-crisis & 1.45 & 0.30 & 0.38 \\
\hline
\end{tabular}

Source: Authors' calculations.

\section{Severity of Shocks}

To examine whether this may have been the case, we have computed an index of monthly changes in "exchange market pressure" for each of our five countries. This index, due to Girton and Roper (1977), is a weighted average of monthly changes in the exchange rate (in percent), in the stock of international reserves (in percent), and in domestic interest rates. ${ }^{9}$ The absolute monthly changes in the index can help determine whether the post-crisis period was

fiscal stimulus package and fundamental reforms in the financial and corporate sectors - contributed to reduced uncertainty (see the rcsults and discussion in section III. D below).

${ }^{9}$ The weights are inversely proportional to the relative variances of the three individual indicators of exchange market pressure, so that each component contributes the same amount of volatility to the index. 
more volatile than the pre-crisis one. ${ }^{10}$ Table 5 below shows the number of observations that exceeded a certain threshold ( 2 percent) during both periods. ${ }^{11}$ These results suggest that, with the exception of Malaysia ${ }^{12}$ and Korea, the post-crisis period may have been a more volatile one for the Asian crisis countries than the pre-crisis one, and especially so for the Philippines and Indonesia.

Table 5: Exchange Market Volatility in the Asian Crisis Countries

\begin{tabular}{lcc}
\hline & \multicolumn{2}{c}{ Share of observations (months) above 2.0} \\
& Pre-crisis & Post-crisis \\
\cline { 2 - 3 } Indonesia & $4.55 \%$ & $68.18 \%$ \\
Korea & $22.73 \%$ & $22.73 \%$ \\
Malaysia & $4.55 \%$ & $0.00 \%$ \\
Philippines & $4.55 \%$ & $31.82 \%$ \\
Thailand & $4.55 \%$ & $9.09 \%$ \\
\hline
\end{tabular}

Source: Authors' calculations.

Accordingly, to correct for the possibility that changes in volatilities in the previous section could just reflect the violation of one of our assumptions-i.e., that shocks have been uniformly severe across countries and periods-we look at the relative volatility of the exchange rate compared to those of reserves and interest rates in each of our countries. Because this provides a crude measure of the relative extent to which foreign exchange market shocks have been absorbed by the exchange rate instead of by changes in reserves or in domestic interest rates, it is in principle independent of the volatility of the environment. The results of these comparisons are reported in Table 6.

The results are consistent with our previous findings for Korea, Malaysia, and Thailand. As in the earlier results, Korea and Thailand appear clearly to be floating more actively after the crisis than before, in the sense that in the post-crisis period shocks tend to be reflected to a greater extent in exchange rate movements rather than in movements in reserves or domestic interest rates. Since the exchange rate has been fixed during the post-crisis period in Malaysia, the results are trivially consistent with our previous ones as well.

For the cases of Indonesia and the Philippines, we had previously attributed across-theboard increases in volatility to a less stable environment in the post-crisis period. Correcting for this effect by using the relative volatility measure, we find that these countries also tended to

${ }^{10}$ Actually, we calculate a weighted average of the absolute changes in each of the series that compound the index. We do this because the movements in the series can compensate with each other, not properly reflecting the size of the shocks.

11 The threshold resulted from looking at a plot of the absolute monthly changes in the indices during both periods. We present the table here for simplicity since the corresponding charts are more difficult to interpret.

${ }^{12}$ See footnote 8 . 
allow greater scope for exchange rate responses to shocks after the crisis than before. In both countries the volatility of the exchange rate relative to that of both interest rates and reserves increased sharply in the post-crisis period. It is worth noting, however, that in all four of the Asian countries that apparently moved to more flexible exchange rates after the crisis, the relative volatility of the exchange rate compared to domestic interest rates was significantly less than that of the "pure floaters." 13 These countries also had relatively greater reserve volatility than Germany, though somewhat less than Japan. ${ }^{14}$

\section{E. Summary}

In short, our results so far suggest that our Asian crisis countries can be divided into three groups:

i. For Korea and Thailand, the post-crisis period was a relatively tranquil one. These countries moved to substantially greater exchange rate flexibility in the post-crisis period, though they appear to have attempted to influence their bilateral exchange rates against the U.S. dollar to a significantly greater extent than have industrial-country "pure floaters." These countries have thus moved in the direction of more flexible rates, but have not moved to the extreme pole of pure (clean) floating.

${ }^{13}$ A possible explanation for this result is that the five Asian countries analyzed here are much more open than Germany or Japan - total trade as a share of GDP on average during 1991-00 was 19 percent for Japan, 53 percent for Germany, about 66 percent for Indonesia and Korea, 86 percent for the Philippines, 93 percent for Thailand, and 187 percent for Malaysia. As a consequence, it is conceivable that the inflationary impact of movements in the nominal exchange rate is larger in the five Asian countries. If the central banks in all countries are equally concerned about inflation, then central banks in the more open Asian economies would have to put heavier weight on exchange rate movements.

${ }^{14}$ In the case of Japan, the relatively high measured reserve volatility was due to a few large spikespresumably associated with isolated episodes of intervention by the Japanese central bank that turned out to be relatively large in the context of a small reserve stock. 
Table 6. Volatility Ratios in Five Asian Crisis Countries

\begin{tabular}{llcc}
\hline \multirow{2}{*}{ Germany } & Pre-crisis & $\begin{array}{c}\text { Exchange rate changes relative } \\
\text { to interest rate changes }\end{array}$ & $\begin{array}{c}\text { Exchange rate changes } \\
\text { relative to reserve changes }\end{array}$ \\
& Post-crisis & 20.92 & 1.87 \\
\multirow{3}{*}{ Chile } & Pre-crisis & 14.72 & 1.98 \\
& Post-crisis & 39.16 & 1.42 \\
Mexico & Pre-crisis & 56.15 & 0.85 \\
& Post-crisis & 0.49 & 0.52 \\
Indonesia & Pre-crisis & 1.27 & 1.05 \\
& Post-crisis & 0.62 & 0.37 \\
Korea & Pre-crisis & 1.53 & 0.94 \\
\multirow{4}{*}{ Malaysia } & Post-crisis & 0.30 & 0.13 \\
\multirow{2}{*}{ Philippines } & Pre-crisis & 2.43 & 1.39 \\
& Post-crisis & 1.08 & 0.28 \\
Thailand & Pre-crisis & 10.80 & 1.44 \\
& Pre-crisis & 0.89 & 0.30 \\
& Post-crisis & 0.00 & 0.00 \\
& Pre-crisis & 0.41 & 0.06 \\
& Post-crisis & 1.98 & 0.65 \\
& & 0.19 & 0.17 \\
\hline
\end{tabular}

Source: Authors' calculations

ii. Malaysia has quite openly fixed its bilateral U.S. dollar exchange rate since September 1998, and has defended this parity primarily through sterilized foreign exchange market intervention rather than by assigning the task of stabilizing the exchange rate to monetary policy. This approach to exchange rate policy may have been facilitated by the country's imposition of restrictions on capital movements but also by the improved regional economic conditions after the September 1998 measures were introduced. ${ }^{15}$

iii. For Indonesia and the Philippines, the post-crisis period has proved to be more turbulent in foreign exchange markets than the pre-crisis one. These countries have responded by allowing the exchange rate to move, by intervening in foreign exchange markets, as well as by using domestic monetary policies to defend the value of the exchange rate. However, the relative weight placed on exchange rate movements as endogenous responses to shocks increased greatly in the post-crisis period, implying that these countries, like Korea and Thailand, have also moved toward more flexible exchange rate regimes. However, like Korea and Thailand as well, they have targeted the exchange rate to an extent that appears to be substantially greater than that practiced in the industrial-country "pure floaters."

${ }^{15}$ It should be noted that as economic situations weakened in Malaysia and the region since late 2000 , the ringgit has come under more pressure. 
In short, contrary to the views of some observers (i.e., McKinnon), there has indeed been a change in de facto exchange rate regimes in all five of these countries between the pre- and post-crisis periods. While none of them have adopted "soft pegs" with unfettered capital movements, neither have they moved to the extreme corner solutions of "hard" pegs or clean floats. In other words, all of them have continued to manage their exchange rates in an active manner, and have thus occupied the supposed "hollow middle" of exchange rate policy. ${ }^{16}$

\section{Objectives of Post-Crisis Exchange Rate Policy}

The basic conclusion of the previous section is that, with the exception of Malaysia, the Asian crisis countries have moved toward allowing greater floating of their exchange rates during the post-crisis period. However, they do not float to the same extent as do the "pure floaters" among industrial countries, as there is substantial evidence that these countries have both intervened in foreign exchange markets as well as adapted domestic monetary policies to influence their exchange rates. The question that we address in this section is why these countries have adopted such practices-i.e., what have been the objectives of post-crisis exchange rate policy in the Asian crisis countries? Our approach will be to consider a variety of possible rationales for the authorities' behavior and examine whether each of them is consistent with the evidence.

\section{A. Reduce Volatility}

A possible reason for "dirty" floating on the part of four of our economies is to stabilize high-frequency exchange rate movements. Indeed, one can argue that exchange rate smoothing may be an appropriate response in the post-crisis period from a Bayesian perspective. Because of the large exchange rate movements that were associated with the crisis (see Figure 1), economic agents may have only weak prior beliefs about the equilibrium level of the nominal (and thus real) exchange rate in these economies in the immediate post-crisis period. Under these circumstances, their exchange rate expectations and market spot rates may be excessively sensitive to market developments and news. In other words, under these conditions "extrapolative" expectations may be more likely to emerge and episodes of overshooting to occur. In the absence of an explicit commitment on the part of the authorities to defend a specific parity, intervention to smooth out high-frequency exchange rate movements may thus help to anchor agents' expectations about the path of the real and nominal exchange rates by removing much of the "noise" from the exchange rate series. This means allowing the nominal bilateral rate to move to its equilibrium level, and intervening only to prevent excessive (stationary) volatility around that level.

If foreign exchange market intervention were solely intended to smooth out highfrequency exchange rate fluctuations, then central banks would be obliged to maintain a stock of foreign exchange reserves to facilitate intervention. The stock of reserves should fluctuate randomly around the level that is judged sufficient for the central bank to retain the option to

\footnotetext{
${ }^{16}$ Annex I provides an in-depth analysis of why our results differ from those of McKinnon.
} 
intervene in the foreign exchange market at its discretion, and it should not exhibit a systematic tendency to increase or decrease over time. Thus, one way to assess whether intervention has been designed only to smooth high-frequency exchange rate fluctuations is to examine the behavior of the stock of reserves over time.

Figure 2 shows the pattern of reserve holding over time in the five crisis countries. All of the countries reached lows in officially recorded reserves within a few months of allowing their exchange rate systems to change, and subsequently they all undertook a substantial accumulation of reserves. Reserve accumulation peaked in most cases during the year 2000 (though in Korea it continued until the end of our sample period). Compared to their minimum levels, at their maximum values reserve stocks approximately doubled in Indonesia, Malaysia, and the Philippines ${ }^{17}$, and they more than quadrupled in Korea. While reserve accumulation seems milder in Thailand (their maximum value exceeded their minimum one by just short of 40 percent), when the unwinding of the central bank's forward position in dollars is taken into account, the rate of reserve accumulation in that country may be at least as large as any of the others. ${ }^{18,19}$

The upshot is that post-crisis foreign exchange market intervention in the five crisis countries was not what one might expect, either from a clean float or from a "dirty" float, if intervention is designed only to smooth out high-frequency exchange rate flucturations. If these countries were smoothing the exchange rate, they were also systematically affecting its level through cumulative purchases of foreign exchange, at least into the year 2000 .

\section{B. Stabilization of the Nominal Effective Exchange Rate}

We have already seen that, except for Malaysia after September 1998, the Asian crisis countries have not chosen to stabilize their bilateral exchange rates against the U.S. dollar. However, we have also seen that the exchange values of their currencies have not been a matter of indifference to these countries; that is, they have not been "clean" floaters. To this we have now added that intervention has not simply been designed to smooth out exchange rate fluctuations.

${ }^{17}$ It should be noted that the situation in the Philippines deteriorated towards the end of the post-crisis period. Reserves doubled between January 1998 and March 2000, but declined steadily thereafterthe total loss in reserves between March 2000 and February 2001 was about US $\$ 2$ billion (14.1 percent of the peak level). Reserves have remained stable at about US $\$ 12.5$ billion since, but the authorities have built up some non-deliverable forwards of almost \$ 1 billion at end July 2001.

${ }^{18}$ The imperfection of our reserves measure should be noted. In particular, it does not take into account central bank obligations in forward markets. As is now well known, Thailand defended the baht during the year prior to the float largely by intervening in forward markets, thereby incurring future dollar liabilities that have not been netted out from the officially reported reserves that we use here.

${ }^{19}$ The implicit monthly growth rate, between the minimum and maximum level, of reserves during the post-crisis pcriod arc 2.4 percent for Indonesia, 4.5 percent for Korea, 2.7 percent for Malaysia and the Philippines, and 1.2 percent for Thailand. 
Figure 2. Post-Crisis Reserve Accumulation in the Five Crisis Countries

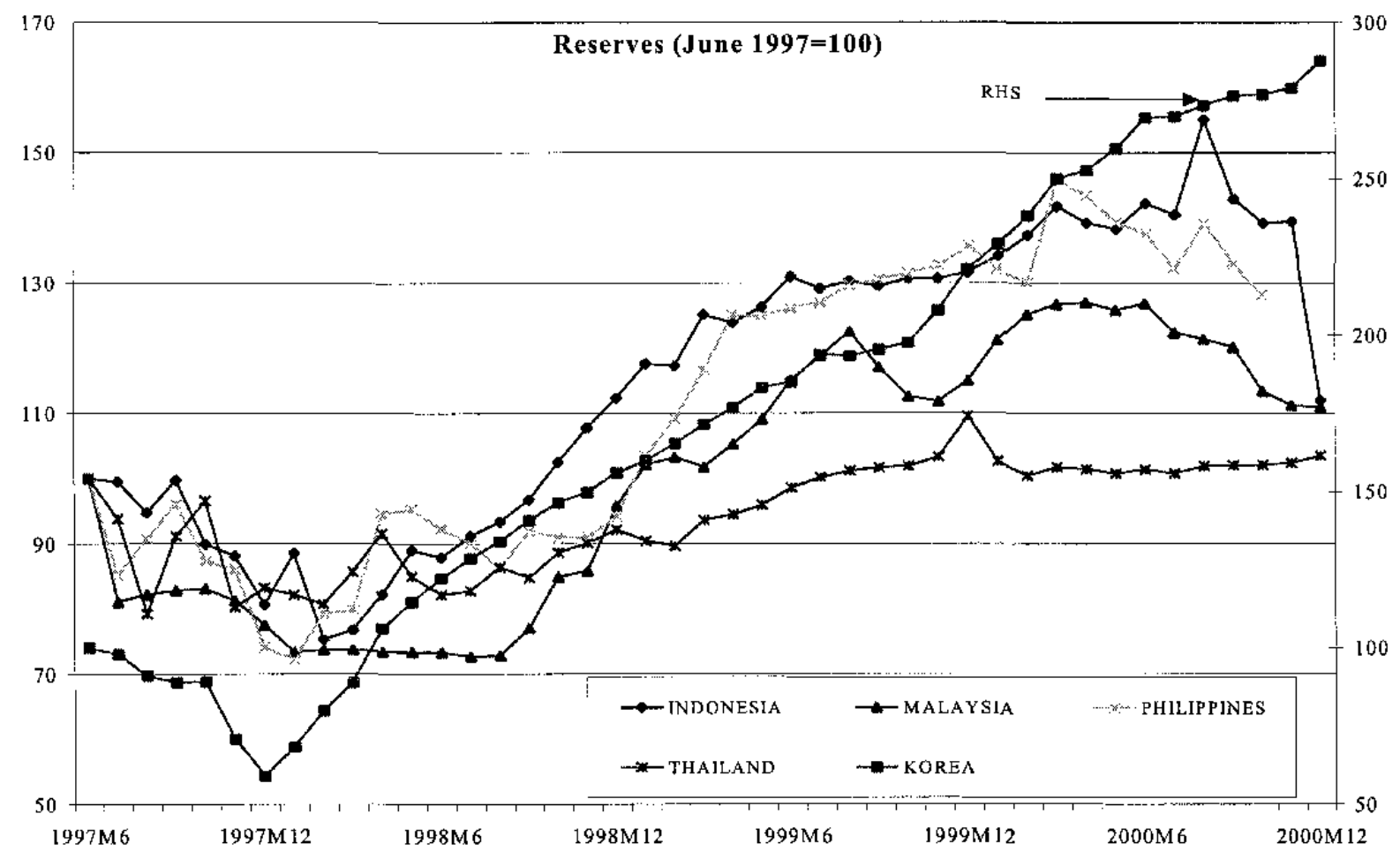

Source: IMF

What, then, has been the objective of intervention? One possibility is that these countries may have been seeking to stabilize the path of the nominal effective exchange rate (NEER) ${ }^{20}$ In other words, they may have been pegging to a currency basket. One can imagine at least two reasons why they might choose to do so:

- $\quad$ First, stabilizing the NEER might represent an attempt to use the exchange rate as a nominal anchor after the crisis. Given that trade with the United States has been decreasing over time as a share of the total trade of the crisis countries, that their other trading partners have been characterized by low and stable inflation rates, and that the value of the U.S. dollar has at times fluctuated sharply against the currencies of their other trading partners, using the exchange rate as a nominal anchor would suggest that the appropriate variable to stabilize would be the NEER.

${ }^{20}$ Note that maintaining stability in the NEER could be compatible with a fluctuating exchange rate against the U.S. dollar, with variability in both reserves and domestic interest rates, and cven with substantial reserve accumulation over short periods of times. All of these have been characteristic of our economies. 
- Second, to the extent that the crisis in each of these countries was in part triggered by exchange rate overvaluation, many analysts have attributed this overvaluation to an excessively rigid pre-crisis peg against the U.S. dollar at a time when the dollar was appreciating relative to the Japanese yen. Thus, one lesson that these countries could have drawn from the crisis would have been that, to the extent that they wish to stabilize some version of their nominal exchange rates, the appropriate version should be one that gives greater weight to the currencies of their other trading partners. This suggests a shift from stabilizing the bilateral rate against the U.S. dollar toward stabilizing something like the NEER.

How can we tell if this has been the objective driving the post-crisis exchange rate policy in our countries? The log of a country's NEER can be expressed as the sum of (the log of) that country's bilateral exchange rate against the U.S. dollar (EXCH), and (the log of) a weighted average of the dollar value of the currencies of the home country's main trading partners, with weights given by the home country's trade weights (DOLLAR). If the bilateral exchange rates against the U.S. dollar were being managed to offset fluctuations in the dollar value of the major trading partners' currencies, we would expect the correlation between EXCH and DOLLAR approach negative one, and those between NEER and both EXCH and DOLLAR to be zero.

As Table 7 shows, this has clearly not been the case. In Indonesia, the Philippines, and Thailand, movements in the bilateral exchange rate against the U.S. dollar have actually been positively correlated with changes in the external value of the U.S. dollar-i.e., changes in the bilateral exchange rates against the U.S. dollar have tended to reinforce the effects on each country's NEER of fluctuations in the external value of the U.S. dollar (Column 2). On the other hand, for Korea and Malaysia we cannot reject the null hypothesis that the two variables have moved independently, though the correlation between them is negative. The upshot is that in none of our five countries has the NEER been simultaneously uncorrelated with movements in bilateral U.S. dollar exchange rates and the external value of the dollar (Columns 3 and 4), as would tend to be the case under a policy of NEER stabilization. Thus, in none of them does the nominal effective exchange rate appear to have been stabilized after the crisis. 
Table 7. Bivariate Correlations Among Nominal Exchange Rates in Five Asian Countries

\begin{tabular}{lccc}
\hline & Correlation between EXCH and DOLLAR & \multicolumn{2}{c}{ Correlation of NEER with: } \\
\hline Indonesia & $0.46^{*}$ & EXCH & DOLLAR \\
Korea & -0.25 & $0.97^{*}$ & 0.24 \\
Malaysia & -0.21 & $0.88^{*}$ & $-0.67^{*}$ \\
Philippines & $0.71^{*}$ & 0.21 & $-0.99^{*}$ \\
Thailand & $0.61^{*}$ & $0.97^{*}$ & $0.53^{*}$ \\
\hline
\end{tabular}

* sig. at standard levels.

Source: Authors' calculations

\section{Stabilization of the Real Effective Exchange Rate}

Countries may care about the behavior of their nominal exchange rates not just because of the potential role of the exchange rate as a nominal anchor, but also because, at least in the short run, the behavior of the nominal exchange rate will influence that of the real exchange rate, which is a key macroeconomic relative price guiding the composition of production and absorption between traded and non-traded goods. Indeed, in the outward-oriented development strategies that all of these formerly "miracle" economies followed up to the time of the crisis, the behavior of the real exchange rate played an important role, as the avoidance of overvalued real exchange rates and the achieving of a stable and predictable path of the real exchange rate were central components of that strategy.

Accordingly, it would not be surprising for post-crisis exchange rate policies in these countries to revert to a concern with the behavior of the real exchange rate, and in particular for it to be the case that, in the wake of the turbulence created in exchange markets by the crisis itself, the authorities in these countries would find it desirable to intervene in support of real exchange rate stability.

Have they indeed done so $?^{21} \mathrm{Just}$ as in the case of the NEER, the real effective exchange rate (REER) can be decomposed into two constituent series: the nominal effective exchange rate (NEER) and the ratio between domestic and weighted trade-partner-country price levels (REL). Has the variability in the NEER played the role of offsetting variability in relative prices? As in the previous section, if it had, we would expect NEER and REL to be negatively correlated, and REER to be uncorrelated both with NEER as well as with REL. These correlations are presented in Table 8. Negative and statistically significant correlation coefficients are evident only in the cases of Indonesia and the Philippines, and the hypothesis that this coefficient is

${ }^{21}$ Notice that our previous finding that stabilizing the nominal effective exchange rate has not been an obvious concern of policy does not preclude this possibility, since nominal effective cxchange rate variability may be requircd to stabilize the real effective exchange rate when the domestic price level becomes unstable relative to those of the country's trading partners. 
minus one fails to be rejected only in the case of the Philippines. However, even in that case, NEER turns out to be substantially more volatile than REL. The result is that REER is highly and significantly correlated with NEER in every case, and with REL as well in the cases of Indonesia, the Philippines, and Korea. In short, there is no evidence here that stabilization of the real effective exchange rate has been the guiding principle of post-crisis exchange rate policy in any of our five countries.

Table 8. Bivariate Correlations Among the Real Exchange Rate and its Components in Five Asian Countries

\begin{tabular}{lccc}
\hline & Correlation between NEER and REL & \multicolumn{2}{c}{ Correlation of REER with: } \\
\hline Indonesia & $-0.57^{*}$ & NEER & REL \\
Korea & $0.49^{*}$ & $0.98^{*}$ & $-0.39^{*}$ \\
Malaysia & -0.30 & $0.99^{*}$ & $0.63^{*}$ \\
Philippines & $-0.96^{*}$ & $0.99^{*}$ & -0.18 \\
Thailand & -0.10 & $0.99^{*}$ & $-0.93^{*}$ \\
& & $0.99^{*}$ & -0.01 \\
\hline
\end{tabular}

Source: Authors' calculations

\section{Smoothing the Pace of Depreciation}

If exchange rate policy was not used to offset the effects of changes in the external value of the U.S. dollar on each country's NEER, or the effects of changes in relative price levels on each country's REER, then what was it used for? One possibility is that it may have been intended to influence the "central tendencies" of the NEER and REER-i.e., the paths around which the NEER and REER have fluctuated on a monthly basis.

We saw in Table 8 that the real effective exchange rate has been very strongly correlated with the nominal effective exchange rate during the post-crisis period in all of our countries. Moreover, except for Malaysia, the nominal effective exchange rate has been highly correlated with the bilateral exchange rate against the U.S. dollar. This suggests that movements in the real effective exchange rate in these countries after the crisis have been driven by changes in their bilateral exchange rates against the U.S. dollar, and this turns out to be the case. ${ }^{22}$ The strong links between the REER and bilateral exchange rates in the four floating-rate countries raises the possibility that exchange market intervention may have been intended to influence the path of the real effective exchange rate.

In what direction might these countries have wished to see the REER move? A logical ex-ante possibility is that they may have wanted to smooth the pace of depreciation. We know that the crisis was associated with extreme exchange rate depreciations in all of these countries,

${ }^{22}$ Correlations between the REER and the bilatcral exchange rate against the U.S. dollar were 0.92 for Indonesia, 0.85 for Korea, 0.21 for Malaysia, 0.96 for the Philippines, and 0.89 for Thailand, all of them statistically significant except for Malaysia. 
and that these depreciations had cataclysmic real consequences because of the severe currency mismatches that characterized the balance sheets of financial institutions and firms. Moreover, we also know that, in consequence, supporting the values of these currencies was an important objective of macroeconomic policy during the crisis in all of these countries. It is reasonable, then, to suppose that exchange rate policy in the post-crisis period may have been directed to the same end.

However, this logical supposition is not supported by the facts. In particular, if exchange rate policy had been aimed at smoothing the pace of depreciation during the post-crisis period, we would have expected the central banks of the former crisis countries to have expended reserves in sustaining the values of their currencies. But as we have seen, just the opposite has been true.

\section{E. Smoothing the Pace of Appreciation}

The accumulation of reserves by the former crisis countries suggests that, to the extent that foreign exchange intervention was conducted with a view to influencing the path of the real effective exchange rate, the intended result may have been exactly the opposite one, that is, these countries may have wanted to smooth the pace of appreciation. If the crisis-induced collapse of their currencies caused their nominal exchange rates to overshoot their equilibrium values, then these currencies would have had a tendency to appreciate in real effective terms during the post-crisis period, to something like their pre-crisis levels or to levels that are only moderately depreciated compared to the pre-crisis levels, depending on whether these currencies tended to be overvalued before the crisis. Intervention would then be intended to resist this appreciation, either by maintaining real effective exchange rates at levels below their equilibrium values or by slowing the rate of return of the real exchange rate to its equilibrium value. ${ }^{23}$ An exchange rate policy of this type would be consistent with the substantial accumulation of foreign exchange reserves during the post-crisis period that we documented earlier in this section.

Why might this be a reasonable objective of policy? First, as we have already indicated, a competitive real exchange rate had long been a linchpin of development policy in these outward-oriented economies. ${ }^{24}$ Second, the crisis had very severe real effects in these

${ }^{23}$ After reaching its lowest level in January 1998, the real effective exchange rate began appreciating in all five countries. This upward trend continued through the end of the post crisis period in both Korca and Malaysia. However, the real exchange rate began depreciating in the second quarter of 2000 in the other three countries. The largest fall occurred in the case of the Philippines, with the real exchange rate depreciating by 13.7 percent between May 2000 and January 2001 . Thus, it is possible to argue that as conditions weakened towards the end of the post-crisis period, the authorities in the Philippines appear to be leaning toward 'smoothing the pace of depreciation' instead of appreciation ( $s c c$ footnote 17).

${ }^{24}$ The concern with competitiveness has been evident throughout the region, as even non-crisis countries such as Singapore and Taiwan floated their currencies in response to the sharp depreciations 
economies, as each of the crisis countries underwent a sharp contraction in real GDP. The maintenance of relatively depreciated real exchange rates would thus also have played a stabilization role by encouraging exports and discouraging imports, thereby helping to stimulate aggregate demand and foster an economic recovery. A similar strategy was followed by Chile after its "twin crises" in the early eighties, as well as by Mexico in the aftermath of its 1994-95 crisis. On the basis of the available evidence, we cannot reject this interpretation of the objectives of post-crisis exchange rate policy among the Asian crisis countries.

\section{F. Accumulation of a Reserve "War Chest"}

Nonetheless, smoothing the pace of appreciation does not represent the only feasible interpretation of the objectives of exchange rate policy in these countries. An alternative interpretation is that the post-crisis moderation of real exchange rate appreciation, rather than representing the ultimate objective of policy, was simply the byproduct of policies undertaken with another purpose in mind, in particular, the accumulation of a "war chest" of international reserves.

At this point, the jury is still out on whether the Asian financial crisis is best interpreted as a solvency or a liquidity crisis. The inability of crisis countries to raise funds on private capital markets is consistent with either interpretation. This inability to raise funds, however, meant that the liquid resources available to each of these countries for the purpose of conducting foreign exchange market intervention were limited to their stocks of usable foreign exchange reserves. Countries in the region that avoided the worst effects of the crisis had in common either a limited degree of integration with international capital markets (China, India, Vietnam), or truly massive foreign exchange reserves (China, Singapore, Taiwan Province of China). Indeed, even Hong Kong SAR, which did not escape a severe attack on its currency in October of 1997, was able to successfully weather that attack partly as a result of its truly enormous stock of foreign exchange reserves. ${ }^{25}$ Figure 3 shows that reserve stocks among the crisis countries were indeed substantially lower than among several countries that weathered the crisis more successfully. ${ }^{26}$

Thus, the desire to accumulate reserves so as to secure a liquidity buffer against future shocks provides an alternative explanation of exchange rate policy in the post-crisis countries. Because reserve accumulation tends to sustain a depreciated value of the currency relative to what would have happened otherwise, while the desire to resist currency appreciation implies foreign exchange market intervention in the form of reserve accumulation, we cannot distinguish between these possible motivations on the basis of the observation that these

undergone by the currencies of the crisis countries, with an eye to preserving their competitive positions in export markets.

${ }^{25}$ Hong Kong SAR also operated a currency board system which may have greatly enhanced the credibility of its commitment to defend the parity of the Hong Kong dollar.

${ }^{26}$ It is important to note that the stock of official reserves overestimates the actual level of reserves in Thailand. This was clearly demonstrated after the devaluation of the baht in July 1997. 
countries have been engaged in substantial reserve accumulation. However, we have some direct evidence that reserve accumulation was an explicit objective of policy, rather than simply a byproduct of an attempt to moderate the appreciation of the real effective exchange rate. The Korean Letter of Intent of November 1999, for example, stipulated an exchange rate policy consisting of "smoothing operations consistent with a further buildup of usable reserves," and a reserve floor was established as part of the Korean program which envisioned a buildup of reserves over time. ${ }^{27}$

Figure 3. Reserve Stocks in Non-Crisis and Crisis Countries, 1996

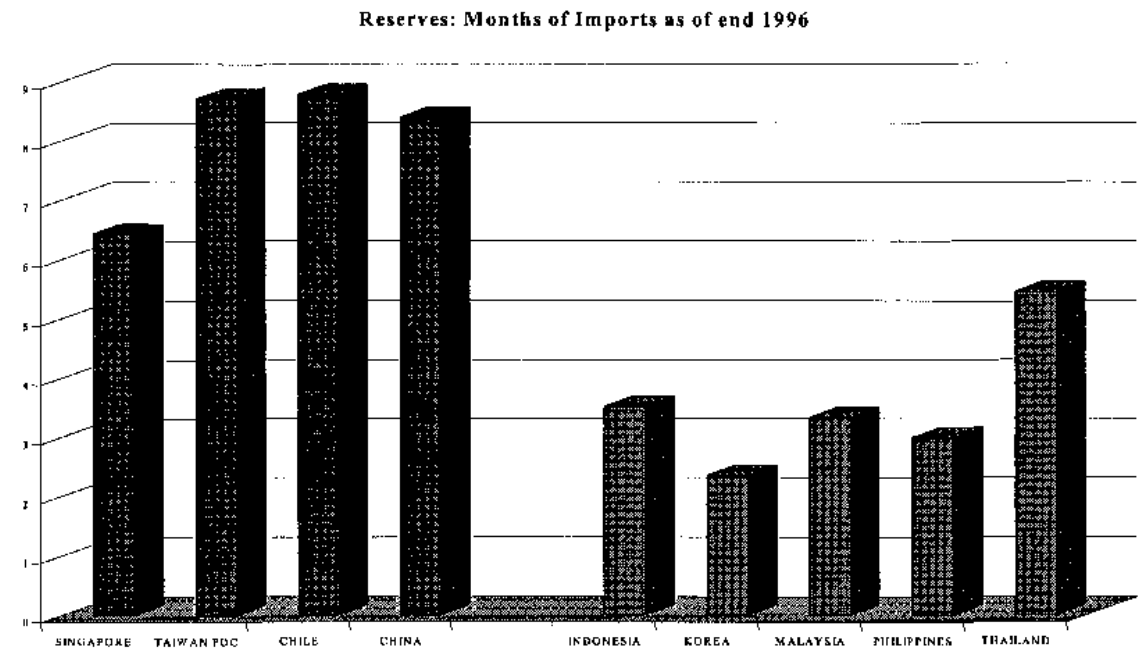

Source: IMF

G. Summary

In short, as we saw in the previous section, the four post-crisis "floaters" among the five Asian crisis countries have allowed substantially more flexibility to their nominal exchange rates than they did before the crisis, but not nearly as much as have the industrial-country "clean" floaters. They moderated exchange rate movements triggered by foreign exchange market shocks through foreign exchange market intervention as well as by conducting domestic monetary policy with an eye toward external objectives.

What were they seeking to achieve in doing so? In this section we have argued that, while they may have intended to smooth high-frequency exchange-rate fluctuations, this could not have been the only objective guiding the behavior of the monetary authorities. In addition,

${ }^{27}$ It should be noted that this objective was dropped in the Letter of Intent of July 2000 , after reserves reached US\$ 90 billion and there were concerns of overheating. Since September 2000 there has been virtually no central bank intervention in foreign exchange, although international reserves kept increasing towards the end of the post crisis period (they reached US $\$ 96.1$ billion in December 2000 and US\$ 99 billion in August 2001). 
their systematic accumulation of reserves during the post-crisis period suggests that, consistent with their long-term development strategies as well as with the short-term need to reactivate their economies, they may have been trying to moderate the appreciation of their real effective exchange rates after the overshooting associated with the crisis, and/or may have been engaging in the accumulation of a reserve "war chest" to employ in the future stabilization of the exchange rate. Note that these arguments apply both to the four "floaters," as well as to the nonfloater case of Malaysia during the post-crisis. Though we cannot distinguish between these objectives on the basis of the cumulative behavior of reserves during the post-crisis period, there is some direct evidence indicating that reserve accumulation was an independent objective of policy.

\section{An Evaluation: Exchange Rate Policy and Post-Crisis Economics}

The post-crisis exchange rate policies of our five countries can thus be characterized as containing three common features: limited flexibility, resistance of real exchange rate appreciation, and reserve accumulation. Is a policy featuring these three components appropriate for these economies? In this section we will consider possible rationales for these policies in the specific post-crisis context of the five Asian crisis countries.

\section{A. Limited Flexibility}

It is worth emphasizing that, while the former crisis countries may have been forced to float in the context of the crisis by their limited ability to resist the substantial pressures that emerged against their currencies, they have had significantly more discretion about their exchange rate policies during the post-crisis period than other floaters. Nevertheless, though they have intervened to smooth exchange rate fluctuations, with the exception of Malaysia they have not reintroduced predictable pegs against the U.S. dollar. Thus, what needs to be evaluated, at least for four of these countries, is the apparent policy of limited-but nonzeroexchange rate variability.

Permitting a greater degree of flexibility to nominal exchange rates while eschewing pre-announced parities has two potential virtues in the post-crisis context:

- $\quad$ Enhanced exchange rate flexibility presumably helps to align perceived de facto exchange rate policy with the de jure exchange rate regime, thus preventing the emergence of an implicit commitment to an exchange rate parity. By not committing the government to defending a fixed parity, and therefore not compromising the government's prestige in any market-induced depreciation of the exchange rate, this policy reduces the incentives for the government to commit resources to a defense of the rate, and thus reduces potential profit opportunities in speculation against the currency. This is simply the standard argument for the view that currency crises (in the form of sharp exchange rate movements) are less likely to occur under floating exchange rates.

- By explicitly creating uncertainty about the future course of the exchange rate, exchange rate variability may discourage the assumption of additional foreign currency risk by 
reducing moral hazard problems associated with the perception of implicit government exchange guarantees.

On the other hand, as argued earlier, some degree of exchange rate smoothing may be an appropriate response in the immediate post-crisis period from a Bayesian perspective, mainly because under such circumstances economic agents may have weak prior beliefs about the equilibrium level of the nominal (and real) exchange rate, thus making "extrapolative" expectations more likely to arise. Intervention to smooth high-frequency exchange rate movements may thus help to anchor agents' expectations about the path of the real and nominal exchange rates, which may be particularly pertinent in post-crisis circumstances. ${ }^{28}$

Preserving the perception that the exchange rate is free to move requires the central bank to abstain from targeting it. Ensuring that the exchange rate does not embark on extreme, selfreinforcing fluctuations may require the central bank to do exactly the opposite. These objectives are thus potentially in conflict. The behavior of the four "floaters" among our five countries can be interpreted as an attempt to strike a balance between these objectives. As mentioned above, eschewing an announced parity while allowing the exchange rate substantial latitude to move in both directions avoids the perception of a de facto peg, such as existed before the crisis. Within that framework, a policy of "leaning against the wind" may help to safeguard against destabilizing speculation based on actual exchange rate movements without jeopardizing the perception of exchange rate flexibility. Thus, the limited but nonzero exchange rate variability allowed by the four "floaters" may represent an attempt to strike a compromise between desirable but potentially conflicting objectives in the post-crisis context.

In contrast to the compromise between these two objectives apparently sought by the other crisis countries, Malaysia opted for the benefits of stability, while completely foregoing those of flexibility. If an intermediate position within the "hollow middle" was optimal for the other countries, why was the same choice not optimal for Malaysia?

One hypothesis is that Malaysia's choice to opt for a corner solution was driven by the fact that, in view of the decision taken by that country in mid-1998 to attempt to recover from the crisis by reflating outside the context of a Fund-supported adjustment program, and given the political dimensions of that decision in that country, it may have faced a much less favorable flexibility-stability tradeoff than other countries in the region. The decision to reflate without the Fund would itself have unsettled the foreign exchange market, and the associated implied replacement of Finance Minister Anwar Ibrahim, the former heir-apparent to Prime Minister Mahathir, would have compounded the effect through the political uncertainty it created. In that context exchange market pressures would have become very severe, and may have dictated the choice to fix the rate and impose capital controls.

${ }^{28}$ If so, as we have noted, it would justify the "smoothing" component of exchange market intervention, but not the systematic reserve accumulation that we actually observe in the five Asian crisis countries. 
In sum, it can be argued that post-crisis exchange rate policies at neither extreme of the exchange regime spectrum may have been appropriate under post-crisis circumstances in all five crisis countries. These policies may have helped to anchor agents' expectations in all of them while, at the same time, introducing some degree of uncertainty in four of them.

\section{B. Smoothing the Pace of Appreciation}

As we have discussed, a byproduct of reserve accumulation is to moderate the appreciation of the nominal exchange rate in the wake of the overshooting associated with the crisis. The resulting relative depreciation of the real exchange rate enhances the competitiveness of these economies, and has thus contributed to the recovery of real activity by encouraging exports and discouraging imports. Figure 4 shows the behavior of the real effective exchange rate in our five countries both before and after the crisis. ${ }^{29}$

In each case, the average real effective exchange rate was more appreciated on average during 1999-2000 than the minimum values reached in early 1998, but more depreciated than its pre-crisis level. This pattern, in which a large part of the real exchange rate depreciation associated with the crisis is sustained for several years after the crisis, was also characteristic of post-crisis recoveries in Chile (after the crisis of 1982) and Mexico (after the crisis of 1994). As shown in Table 9, in all of these cases the crisis was associated with a short and sharp contraction in real economic activity, and the recovery in real economic activity was accompanied by a rapid acceleration in export growth, fueled in part by improved competitiveness.

\footnotetext{
${ }^{29}$ See footnote 23 .
} 
Figure 4

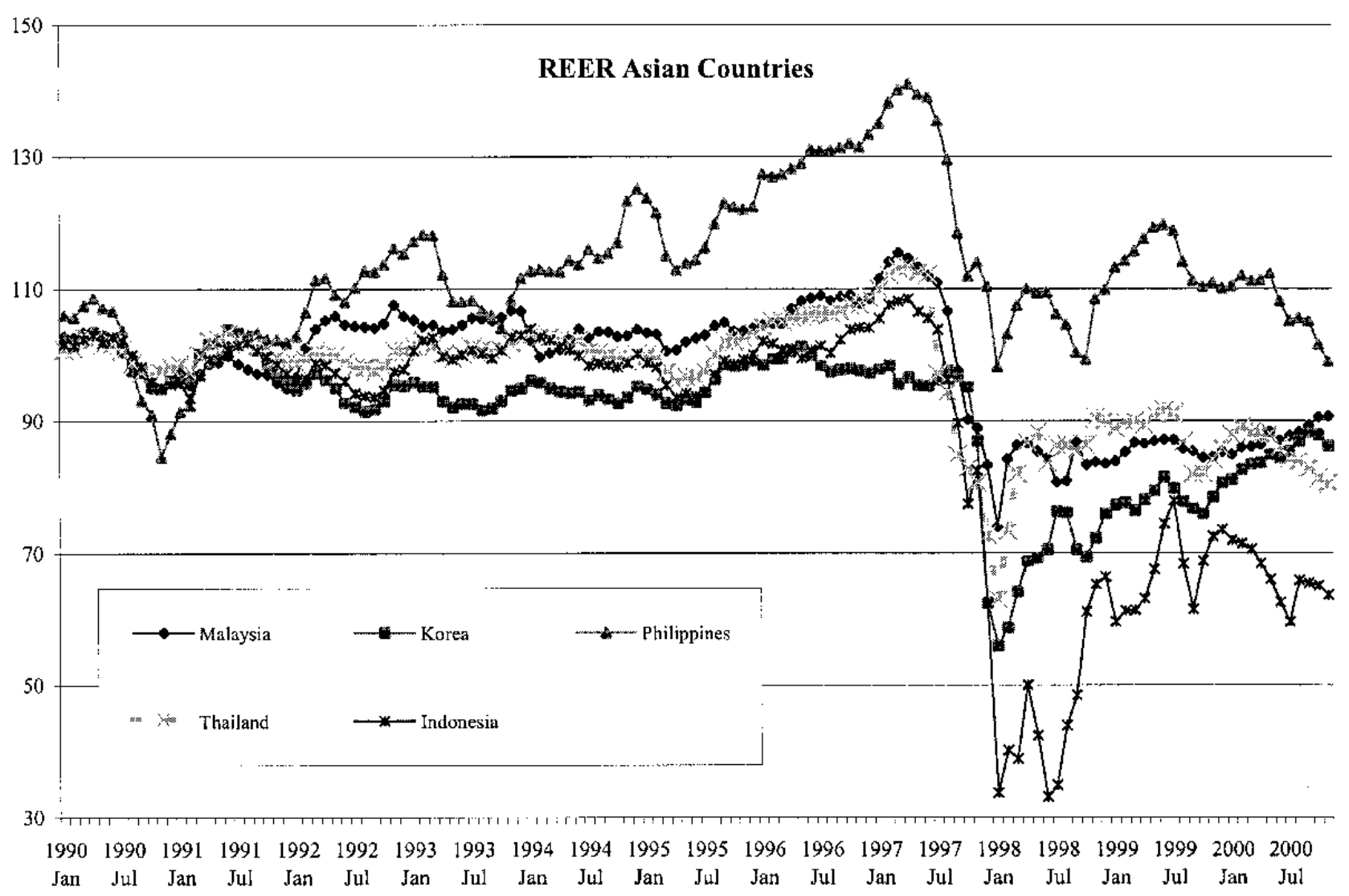

Source: IMF

One way to interpret what these countries have done in the area of exchange rate policy, then, is as a component of a recovery strategy for real economic activity, other components of which have included a loosening of both fiscal and monetary policies after an initial tightening in the immediate aftermath of the crisis intended to restore creditor confidence. Given that an excessive loosening of fiscal and monetary policies to reactivate these economies may have threatened a fragile restoration of confidence, relative real exchange rate depreciation may have had an advantage as an instrument of policy that could promote recovery without undermining confidence. Moreover, the outward orientation that characterized the development strategies of all of these economies-and the consequent large size of the traded goods sector ${ }^{30}$-may have made real exchange rate depreciation a relatively powerful tool in stimulating domestic economic activity.

\footnotetext{
${ }^{30}$ See footnote 13 .
} 
Table 9. Real GDP and Volume of Exports Growth During Post-Crisis Recovery in Eight Crisis Countries (\%)

Chile

Average growth in Export Volume

Avcrage growth in Real GDP

Mexico

Avcrage growth in Export Volume

Average growth in Real GDP

Thailand

Average growth in Export Volume

Average growth in Real GDP

Philippines

Average growth in Export Volume

Average growth in Real GDP

Malaysia

Average growth in Export Volume

Average growth in Real GDP

Korea

Average growth in Export Volume

Average growth in Real GDP

Indonesia

Average growth in Export Volume

Average growth in Real GDP
1983

0.07

$-3.49$

1995

12.1

$-6.17$

1998

6.54

$-10.8$

1998

4.89

$-0.59$

1998

$-3.86$

$-7.36$

1998

13.3

$-6.69$

1998

8.88

$-13.1$
1984-88

10.16

5.74

1996-99

13.0

5.16

1999-00

14.2

4.31

1999-00

11.5

3.71

1999-00

14.0

7.18

1999-00

19.1

9.85

1999-00

4.19

2.79

Source: IMF

\section{Reserve Accumulation}

Third, and perhaps most importantly, reserve accumulation may actually be an important component of a natural transition to a new regime of floating exchange rates. In recent years, we have become increasingly aware that countries that do not announce fixed exchange rate parities tend to float very differently from each other. In particular, Hausmann and others (2000) have noted that among floaters, some countries maintain much larger stocks of reserves than others, and use them to intervene much more actively in the foreign exchange market, thus providing much more stability to the nominal exchange rate than would have been observed otherwise. They have identified two systematic influences on countries' decisions to intervene more or less actively, and thus to maintain larger or smaller stocks of reserves: the degree of exchange rate "pass-through" in their economies, and the extent to which agents in these economies are able to borrow externally in their own currencies. The inability of many developing country agents to borrow in their own currencies was dubbed "original sin" by Eichengreen and Hausmann (1999). Empirically, the severity of "original sin" proved to be the most important factor in explaining the size of the reserve stocks maintained by floaters.

While Hausmann and others have documented an empirical regularity in the way that countries float, McKinnon (2000) has provided an explicit argument linking "original sin" to 
optimal exchange rate policy that actually goes much further. Essentially his point is that, unless countries credibly commit to a fixed long-run value of their nominal exchange rates, expectations of devaluation will create interest rate differentials that will make it very expensive for domestic residents to hedge foreign exchange rate risk. Thus, if "original sin" prevails, currency mismatches will be the rule in emerging economies that are open to capital flows. Such mismatches will aggravate the real consequences of exchange rate crises, as they evidently have done in the Asian countries. It is possible to add to this that such mismatches will also make currency crises more likely to happen (see Montiel (1999)). The upshot is that in the presence of "original sin," countries should credibly commit themselves to permanent exchange values of their currencies.

Whether for the purpose of managing floats or to secure a permanent long-run value for the currency, being in the position to intervene extensively in the foreign exchange market requires the accumulation of a sufficiently large stock of reserves by countries that are subject to "original sin." As it happens, the five countries that concern us are among those included in the original study by Hausmann and others, and according to the indicators used in that paper, all of them fit this description. Since all of them went through currency crises that featured substantial depletion of their reserve stocks, one justification of their post-crisis exchange rate policies could be that these policies represent a transitory period of reserve accumulation. The latter is needed to put these countries in the position to manage their exchange rates much more actively over the indefinite future, and thus provide the protection against currency mismatches in the presence of "original sin" that would be expected by Hausmann and others as well as by McKinnon.

These arguments suggest that a policy of smoothing-cum-reserve accumulation may actually have been optimal for these five Asian countries in the post-crisis period. This policy simultaneously achieves three goals:

- $\quad$ By reducing the noise content in exchange rate movements, it makes it easier for economic agents to extract information from exchange rate movements, and thus promotes the efficient allocation of resources.

- $\quad$ By temporarily preserving an overly depreciated real exchange rate, it promotes economic recovery in these heavily outwardly-oriented economies.

- $\quad$ By accumulating a reserve cushion, it provides the means through which these victims of "original sin" can protect themselves in the future from the disruptive consequences of currency mismatches.

These ex ante considerations, coupled with a very strong macroeconomic performance in the crisis countries during the post-crisis period (not only the large reserve accumulation itself, but also a large current account adjustment achieved with a rapid growth recovery and without inflation) give grounds for a favorable verdict on exchange rate policies in the Asian countries during the post-crisis period. 
Moreover, from a narrower perspective that focuses on the sustainability of the exchange rate regime itself, these policies also appear to have been successful. Because the "dirty floats" in which these countries have engaged imply that the exchange rate has explicitly or implicitly been a target of macroeconomic policies (that is, these countries have not been at the extreme end of "pure floating" in the exchange regime distribution), their currencies are in principle vulnerable to speculative attacks that would force the authorities away from their exchangemarket intervention rules. Such attacks, whether successful or not, would manifest themselves in extreme observations of the components of the "exchange market pressure indices"-reserve changes, interest rates, and/or exchange rate changes. Yet, as shown in Figure 5, all of these indicators have been relatively tranquil (non-positive) in the post-crisis period. ${ }^{31}$

Figure 5. Post-Crisis Exchange Market Pressure in the Five Crisis Economies

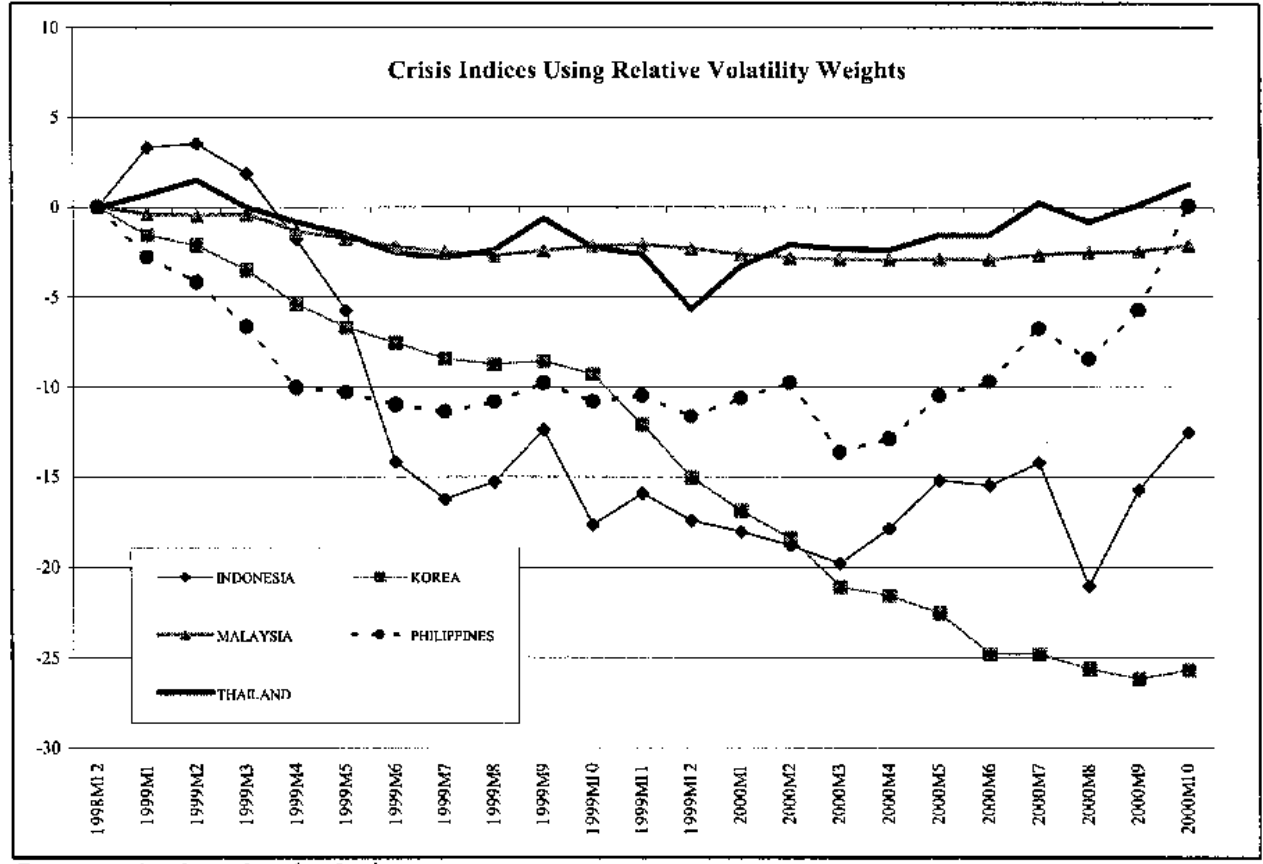

Source: Authors' calculations

These results suggest that the total policy package in these countries has been a credible one, perceived as sustainable by the markets. In other words, although these countries have moved along the exchange regime continuum away from the 'fixed' toward the 'flexible' end, they have not gone all the way. Yet, up to end 2000, at least, they do not appear to have been penalized by the markets for not having done so.

${ }^{31}$ Figure 5 computes the indicator of exchange market pressure using December 1998 as a benchmark. Changes in reserves, exchange rates, and interest rates are weighted by the inverse of their volatilities during the sample period. With regards to the weakening situation in the Philippines toward the end of the post-crisis period see footnotes 17 and 23. 


\section{LOOKING AHEAd: Some QuaLIFICATIONS}

While these considerations would seem to suggest that exchange rate policy has been conducted in a fairly benign fashion in these countries, given their post-crisis circumstances, these conclusions are subject to some qualifications. In particular, there is an alternative perspective that puts matters in a somewhat less favorable light, suggesting that the post-crisis exchange rate policies pursued in the five countries we have studied constitute at best a secondbest policy response to the persistence of some important domestic distortions, the removal of which has been the explicit objective of policy after the Asian financial crisis. Thus, the exchange rate policies that have been pursued in these countries in effect recognize the incomplete success of policies directed to the removal of such distortions, and can thus be interpreted as transitory in nature. As policy succeeds in diminishing the severity of these distortions, exchange rate policy should be modified accordingly.

This alternative perspective begins by questioning the role of nominal exchange rate stability in avoiding the consequences of currency mismatches. The key point is that the presence of "original sin" does not imply that currency mismatches and their consequences can be avoided only through stabilization of the nominal exchange rate. If this link is broken, then "original sin" cannot be used to justify the maintenance of large reserve stocks by the Asian crisis countries.

Countries tend to hold large amounts of reserves while floating in order to retain the option of preventing large depreciations of the domestic currency. They do this, according to Hausmann and others (2000), precisely because the monetary authorities are aware of the presence of severe currency mismatches in the balance sheets of domestic economic agents, and these mismatches increase the costs - as perceived by the authorities - that are associated with large exchange rate movements. But why do large policy-relevant mismatches arise in the first

place? Both Hausmann and others as well as McKinnon (2000) attribute them to "original sin." McKinnon argues that the link between "original sin" and exchange rate stabilization operates through the disincentives for the financial hedging of exchange rate risk created by interest rate differentials that arise from the risk of currency devaluation. Currency mismatches arise simply because it is too expensive to hedge exchange rate risk in such a situation. Thus, "original sin" is linked to large policy-relevant currency mismatches, which gives rise to an optimal desire for exchange rate stabilization on the part of the authorities, which in turn causes them to wish to hold large amounts of reserves.

But, taking "original sin" as a given, it is not obvious that "excessive" currency mismatches should result, for two reasons:

(a) First, many agents in open economies possess natural "real" hedges against exchange rate risk, in the form of assets devoted to the production of traded goods. Agents whose assets and liabilities are both effectively denominated in foreign currency are obviously not vulnerable to exchange rate risk. For such agents, "original sin" does not give rise to currency mismatches. The potential scope for external borrowing in foreign exchange without incurring currency risk in a given economy depends on the size of that 
economy's traded goods sector. For relatively open economies, such as the five Asian crisis countries, this scope is potentially quite large. ${ }^{32}$

(b) The problem is, of course, that under "original sin" foreign currency debt may be incurred by agents that do not possess such natural hedges, giving rise to currency mismatches. But in principle this is just one among many economic risks that markets allocate. This source of risk, like any other, would presumably raise the cost of capital to the agents undertaking it, and thus be efficiently allocated by the market. In the presence of "original sin," then, the extent of external borrowing in foreign currency by agents for whom such borrowing would tend to create currency mismatches should be naturally restricted by the market, leaving no argument for policy intervention in the form of exchange rate stabilization.

Thus, both because currency mismatches may not arise and because if they do they may not be sub-optimal, the link between "original sin" and the optimality of exchange rate stabilization may be a tenuous one, simply because "original sin" may not give rise to policyrelevant currency mismatches.

However, this raises the issue of whether agents may not be induced to undertake excessive currency risk in the presence of "original sin" by market distortions such as the moral hazard problems that arise in the context of poorly capitalized and supervised financial intermediaries, or by the expectation of bailouts among well-connected firms in the real sector. When such distortions are important, currency mismatches can indeed become excessive, and this suggests a second-best argument for stabilizing the exchange rate. ${ }^{33}$ Just such a situation is typically blamed for the severity of the financial crisis in Asia (and other crises in the past), and indeed is probably implicit in the analyses by Hausmann et.al. and by McKinnon. It is quite likely that it accounts for the "fear of floating" that characterized the Asian countries prior to the crisis.

The key question, of course, concerns the relevance of this analysis for post-crisis Asia. Much of the post-crisis restructuring of these economies has been designed precisely to reduce the incidence of such moral hazard problems by improving the regulatory and supervisory framework for the financial sector, capitalizing banks, and addressing problems of corporate

32 If the traded goods sector accounts for 30-40 percent of GDP, for example, and the capital-output ratio is approximately 3 , the entire capital stock of the traded goods sector could be financed with foreign currency borrowing of around 90-120 percent of GDP without incurring currency mismatches, a figure that is greater than the forcign-currency debt of all the Asian crisis countries except for Indonesia - in 1998, Indonesia's foreign debt was about 172 percent of GDP, while for the other four countries this ratio fluctuated between 44 and 77 percent (source: World Debt Tables).

${ }^{33}$ Some observers have argued that stabilizing the exchange rate may itself create excessive currency mismatches, but it is hard to see why this should occur in the absence of the distortions discussed previously-i.e., stabilizing the exchange rate should not increase external borrowing unless agents believe (ex-ante) that associated with it there is a greater chance of a bail-out. 
governance. To the extent that this process is incomplete, and that incentives remain in place for domestic agents to take on excessive currency risk, then the reserve accumulation objective for future exchange rate stabilization purposes would appear to be justified, but only as a transitory, second-best policy response to the persistence of domestic distortions. Since holding foreign exchange reserves is a costly activity, as these problems are addressed and resolved, the maintenance of large stocks of foreign reserves by Asian central banks would no longer be justified on the basis of "original sin."

Has reserve accumulation already proceeded beyond the optimal point, given the circumstances of these economies? Unfortunately, this is a question on which we can shed little light. The reason is that, in the presence of currency mismatches, the level of reserves required to protect a country against a successful speculative attack in theory depends on a variety of characteristics of the economy, so no simple benchmark that ignores such country-specific characteristics would be appropriate to judge the adequacy of reserve levels. ${ }^{34}$

\section{SUMMARY AND CONCLUSIONS}

The basic questions we have addressed in this paper are: what exchange rate policies have the Asian crisis countries pursued in the post-crisis period, why have they done so, and how do we evaluate these policies? Moreover, we would like to use the post-crisis experience of these countries do draw lessons about exchange rate policies under conditions of high financial integration in other countries.

In summarizing our results, it is useful to begin with a rather obvious observation: the simple classification of exchange rate regimes into "hard pegs," "soft pegs," and "floating" is a fiction. In practice, exchange rate regimes operate along a continuum. The crisis simply caused the Asian crisis countries to move along this continuum. But this move has not been uniform within the region:

(a) Malaysia moved in the direction of much greater fixity and less integration with world capital markets.

(b) Korea and Thailand appear to have entered a post-crisis (i.e., tranquil) period in 19992000. During this period, they have maintained or increased their degree of integration with world capital markets and moved in the direction of greater flexibility, but not to the extreme pole of clean floating.

(c) Because of domestic political uncertainties, it is not so clear that the Philippines and Indonesia truly moved into a post-crisis period during 1999-2000. Relative to the precrisis period, both countries have altered their exchange rate regimes in the direction of greater flexibility, however.

${ }^{34}$ These characteristics include the extent of currency mismatches, the amount of economic damage that their presence can do in the event of a sharp depreciation, the economy's current account deficit, and its stock of short-term external obligations. See Montiel (1999). 
While all of these countries have moved along the exchange rate regime continuum, none of them have opted to jump to either of its extreme poles. If we define the intermediate range of exchange rate regimes as consisting of those in which exchange rates continue to be actively managed, with or without explicit numerical exchange rate targets, these countries are squarely within that range. In that sense, their post-crisis experience suggests that the "middle" has not become as hollow as is sometimes claimed.

How well have these modifications in their exchange rate regimes served the Asian crisis countries? The most plausible interpretation of the objectives of exchange rate policy in these countries is that they were designed to achieve three objectives: to stabilize highfrequency exchange rate movements, ${ }^{35}$ to slow the pace of real appreciation after the overshooting associated with the crisis, and to accumulate a "war chest" of liquid foreign exchange reserves. We have argued that all of these were reasonable objectives of policy in the post-crisis context.

Moreover, these post-crisis regimes have been successful both from the narrow perspective that they have apparently been judged sustainable by the markets (i.e., they have not been subjected to extreme episodes of "exchange market pressure") and from the broader perspective that, especially in countries that have avoided political instability, they have been associated with very successful macroeconomic performance, both in terms of real activity as well as of the economies' external accounts. Growth has picked up rapidly, inflation has remained low, and current accounts have adjusted rapidly.

Is there a link between the exchange rate practices adopted and these measures of performance? On this we have offered little evidence. We can speculate that the removal of the "one-way bet" in the foreign exchange market, together with the crisis-induced real exchange rate overshooting, may have made a difference in preventing the emergence of exchange market pressures, and that the depreciated real exchange rate together with the accumulation of large stocks of reserves, may have respectively supported aggregate demand and enhanced confidence.

But there is also a darker side to exchange rate policies in these countries. In particular, reserve accumulation may have been a substitute for other measures that need to be undertaken in these economies, such as the complete elimination of implicit guarantees and expected government bailouts, or moral hazard behavior resulting from the existence of undercapitalized banks, etc. To the extent that these measures have been absent and/or remain incomplete, reserve accumulation is best interpreted as a second-best transition strategy, and the authorities may actually have had little discretion over its adoption. Given the incompleteness of such

${ }^{35} \mathrm{Wc}$ argued in section III that smoothing could not be the only objective as all the countries accumulated a significant amount of reserves in the post-crisis. However, it is plausible that smoothing was the ultimate objective and the accumulation resulted from an initial low level of reserves. 
measures, however, the chosen exchange rate policy is an appropriate one. Nonetheless, from this perspective, the chosen exchange rate policy represents a symptom of something that is wrong or unfinished, rather than a component of an optimal policy package. Once these other components of reform have been completed in the crisis countries, continuation of the chosen exchange rate policy may prove to be sub-optimal, since a policy of floating with a large reserve "war chest" could be a wasteful of scarce national resources if intervention cannot be justified on second-best grounds.

Finally, what lessons can be drawn for other countries? One tentative lesson is that the size of the "middle" that is actually "hollow" is probably small for at least two reasons. First, what enhanced financial integration has undoubtedly done is made it far more difficult for financially integrated countries to sustain "soft" pegs, simply because capital markets will not allow domestic policy mistakes to go unpunished. But whether there is literally no scope for such regimes depends on whether the domestic authorities can avoid vulnerability through their policy choices. In other words, the part of the "middle" that may be "hollow" is the maintenance of explicit or implicit "soft" pegs with unfettered capital movements and potentially skeptical capital markets.

That is the lesson of pre-crisis Asia, where policy mistakes were not avoided and "soft" pegs fell apart through the reactions of unfettered capital markets. In this paper we have argued that it is also the lesson of post-crisis Asia. In the face of capital markets made skeptical by previous experience, Malaysia abandoned unfettered capital markets, while the other countries abandoned explicit or implicit pegs.

Second, it is also the lesson of post-crisis Asia that this truly "hollow" space in the middle may actually be rather small, in the sense that a wide range of intermediate regimes may be both feasible and desirable, depending on country circumstances Specifically, under postcrisis conditions, if the fragility of domestic balance sheets rules out "hard" pegs as an option (because of the strains imposed by periods of high interest rates that are needed to defend the peg), a "dirty" float designed to resist real appreciation and accumulate reserves has much to recommend it over the polar extreme of "clean" floating. 


\section{Asian Crisis Countries in McKinnon}

As indicated in the text, McKinnon (2000) has drawn the conclusion that, with the exception of Indonesia, the Asian crisis countries have essentially reverted to a dollar standard in the post-crisis period. McKinnon bases his interpretation of exchange rate policy in these countries on regressions of the form:

$$
\begin{aligned}
(\Delta \% \text { loc. currency/SWF })= & \beta_{1}+\beta_{2}(\Delta \% \text { US\$/SWF })+\beta_{3}(\Delta \% \text { JP } ¥ / \mathrm{SWF}) \\
& +\beta_{4}(\Delta \% \mathrm{DM} / \mathrm{SWF})+\varepsilon
\end{aligned}
$$

where SWF denotes the Swiss franc, JP¥ the Japanese yen, and DM the German mark. He emphasizes the coefficient and standard error of the dollar/swf rate, finding it to be close to unity with a small standard error both before and after the crisis for Korea, the Philippines, and Thailand, and concludes that this suggests that these currencies have effectively been re-pegged against the U.S. dollar.

It is true that this coefficient would be close to unity, its standard error would be small, and the equation would have very large explanatory power if the currency in question were tied to the dollar through a fixed-rate arrangement. Thus, if one knows that a currency is fixed to a basket, but does not know the composition of the basket, this equation can be used to estimate the composition of the basket from observed exchange rate movements.

But it is not true that if the coefficient is close to unity and its standard error small, this implies the existence of a fixed-rate basket arrangement. The same result could emerge under a floating exchange rate regime. The correlation between the bilateral exchange rate of the domestic currency and that of the U.S. dollar against a third currency depends on the extent to which the domestic currency and the U.S. dollar experience similar shocks. The prevalence over the sample period of symmetric shocks affecting the domestic economy and the United States, or the presence of strong channels of transmission for economic shocks ('contagion') from the U.S. to the domestic economy would tend to magnify the size of this correlation. Thus, the magnitude of the coefficient of the bilateral exchange rate of the U.S. dollar against a third currency in the regression above and the precision with which its is estimated would tend to depend on the strength of economic links between the economy in question and the United States.

The explanatory power of the regression under flexible exchange rates, on the other hand, would depend on the incidence of asymmetric shocks (shocks that only affect the domestic economy, but are not transmitted back to the United States). The stronger such shocks, the smaller the explanatory power of the regression. Thus, McKinnon's results are consistent either with a tight peg against the U.S. dollar (his preferred interpretation) or with a much looser currency link to the dollar combined with tight economic links to the dollar area and a relative absence of independent shocks during the sample period. Based on the evidence in the main text, we prefer the latter interpretation. 
To support our view, we have conducted similar exercises for Switzerland and Chile. In the former case, the Swiss franc has long been considered one of the "pure floaters," while in the latter case there was an explicit change in the foreign exchange regime in the direction of a much greater floating. Running regressions similar to (A.1) we derived the following results:

Table A.1 Switzerland

\section{1.- Pre-crisis period}

\begin{tabular}{lrlrr}
\hline $\begin{array}{l}\text { Dependent Variable: SF } \\
\text { Method: Least Squares }\end{array}$ & & \multicolumn{3}{l}{ Sample: 1995:07 1997:06 } \\
& & \multicolumn{2}{l}{ Included observations: 24} \\
\hline Variable & Coefficient & Std. Error & t-Statistic & Prob. \\
\hline C & -0.001410 & 0.002812 & -0.501312 & 0.6214 \\
DM & 1.190645 & 0.121715 & 9.782260 & 0.0000 \\
YEN & -0.005156 & 0.083750 & -0.061559 & 0.9515 \\
\hline R-squared & 0.860328 & Mean dependent var & 0.010416 \\
Adjusted R-squared & 0.847025 & S.D. dependent var & 0.032141 \\
S.E. of regression & 0.012571 & Akaike info criterion & -5.798396 \\
Sum squared resid & 0.003319 & Schwarz criterion & -5.651139 \\
Log likelihood & 72.58075 & F-statistic & 64.67588 \\
Durbin-Watson stat & 1.280502 & Prob(F-statistic) & 0.000000 \\
\hline Note: the results remain qualitatively identical after correcting for first order autocorrelation.
\end{tabular}

\section{Post-crisis period}

\begin{tabular}{crlrr}
\hline $\begin{array}{l}\text { Dependent Variable: SF } \\
\text { Method: Least Squares }\end{array}$ & & \multicolumn{2}{l}{ Sample: 1999:02 2001:01 } \\
& & \multicolumn{2}{l}{ Included observations: 24 } \\
\hline Variable & Coefficient & Std. Error & t-Statistic & Prob. \\
\hline C & -0.001910 & 0.001579 & -1.209224 & 0.2400 \\
EURO & 0.959883 & 0.054514 & 17.60795 & 0.0000 \\
YEN & -0.037723 & 0.057977 & -0.650653 & 0.5223 \\
\hline R-squared & 0.936590 & Mean dependent var & 0.006599 \\
Adjusted R-squared & 0.930551 & S.D. dependent var & 0.027951 \\
S.E. of regression & 0.007366 & Akaike info criterion & -6.867411 \\
Sum squared resid & 0.001139 & Schwarz criterion & -6.720154 \\
Log likelihood & 85.40893 & F-statistic & 155.0901 \\
Durbin-Watson stat & 2.309603 & Prob(F-statistic) & 0.000000
\end{tabular}

Note that the coefficient on the DM/Euro was close to unity and significant in both periods, and that the regression appears to possess a high degree of explanatory power. This regression would appear to have the (counterfactual) implication that the Swiss franc was tied to the DM/Euro in both periods. Similarly, turning to the results of a specification for Chile identical to the one used by McKinnon for the Asian countries, we obtain the following results: 
Table A.2 Chile

\section{1.- Pre-crisis period}

\begin{tabular}{crcrr}
\hline $\begin{array}{l}\text { Dependent Variable: PESO } \\
\text { Method: Least Squares }\end{array}$ & & \multicolumn{3}{l}{ Sample: 1995:07 1997:06 } \\
& & \multicolumn{4}{l}{ Included obscrvations: 24} \\
\hline Variable & Coefficient & Std. Error & t-Statistic & Prob. \\
\hline C & 0.003294 & 0.002795 & 1.178842 & 0.2523 \\
DOLLAR & 0.976946 & 0.116533 & 8.383407 & 0.0000 \\
DM & -0.313771 & 0.289633 & -1.083337 & 0.2915 \\
YEN & 0.294248 & 0.083813 & 3.510784 & 0.0022 \\
\hline R-squared & 0.894775 & Mean dependent var & -0.004814 \\
Adjusted R-squared & 0.878991 & S.D. dependent var & 0.035867 \\
S.E. of regression & 0.012477 & Akaike info criterion & -5.778866 \\
Sum squared resid & 0.003113 & Schwarz criterion & -5.582523 \\
Log likelihood & 73.34639 & F-statistic & 56.68954 \\
Durbin-Watson stat & 2.002477 & Prob(F-statistic) & 0.000000 \\
\hline
\end{tabular}

\section{Post-crisis period}

\begin{tabular}{crrrr}
\hline $\begin{array}{l}\text { Dependent Variable: PESO } \\
\text { Method: Least Squares }\end{array}$ & \multicolumn{4}{c}{ Sample(adjusted): 1999:02 2001:01 } \\
& \multicolumn{3}{c}{ Included observations: 24 after adjusting endpoints } \\
\hline Variable & Coefficient & Std. Error & t-Statistic & Prob. \\
\hline C & 0.009520 & 0.007891 & 1.206464 & 0.2417 \\
DOLLAR & 1.091868 & 0.384462 & 2.839987 & 0.0101 \\
EURO & -0.757272 & 1.051387 & -0.720259 & 0.4797 \\
YEN & 0.047385 & 0.284342 & 0.166647 & 0.8693 \\
\hline R-squared & 0.480469 & Mean dependent var & 0.001194 \\
Adjusted R-squarcd & 0.402540 & S.D. dependent var & 0.046370 \\
S.E. of regression & 0.035842 & Akaike info criterion & -3.668385 \\
Sum squared resid & 0.025693 & Schwarz criterion & -3.472043 \\
Log likelihood & 48.02062 & F-statistic & 6.165432 \\
Durbin-Watson stat & 2.410064 & Prob(F-statistic) & 0.003847
\end{tabular}

Chile has explicitly moved - in the absence of a crisis - toward a greater degree of exchange rate flexibility in the second of the two sample periods reported above. Yet the regression reveals an increase in the coefficient on the U.S. dollar during the second period. We conclude from these results that regressions of this type provide an unreliable indicator of exchange rate policies. 


\section{References}

Calvo, Guillermo, and Carmen Reinhart, 2000a, "Fear of Floating," National Bureau of Economic Research Working Paper 7993 (November). Also in

http://www.bsos.umd.edu/econ/ciecrp.htm (version September 2000)

- 2000b, "Fixing for Your Life," Forthcoming in the Brookings Trade Forum 2000, Policy Challenges in the Next Millennium (Washington, DC: Brookings Institution). Also in http://www.puaf.umd.edu/faculty/papers/reinhart/papers.htm

Eichengreen, Barry, and Ricardo Hausmann, 1999, "Exchange Rates and Financial Fragility," 1999 Pacific Basin Conference: Financial Crises in Emerging Markets (September).

Fischer, Stanley, 2001, “Exchange Rate Regimes: Is the Bipolar View Correct?” International Monetary Fund, mimeo. In http://www.imf.org/external/np/speeches/2001/010601a.htm

Girton, Lance, and Don Roper, 1977, "A Monetary Model of Exchange Market Pressure Applied to the Postwar Canadian Experience," American Economic Review, Vol. 67, No. 4 (September) pp. 537-48.

Hausmann, Ricardo, Ugo Panizza, and Ernesto Stein, 2000, "Why Do Countries Float The Way They Float?" Inter-American Development Bank, May. In http://www.iadb.org/RES/working_papers list.cfm?CODE=WP-418

Levy Yeyati, Eduardo, and Federico Sturzenegger, 1999, "Classifying Exchange Rate Regimes: Deeds vs. Words," mimeo, Universidad Torcuato Di Tella. In http://www.utdt.edu/ ely/papers.html

McKinnon, Ronald I., 1999, "The East Asian Dollar Standard: Life After Death?" In http://www-econ.stanford.edu/faculty/workp/swp99017.html

- 2.-. 2000, "After the Crisis, the East Asian Dollar Standard Resurrected: An Interpretation of High-Frequency Exchange Rate Pegging," mimeo, Stanford University. In http://www-econ.stanford.edu/faculty/workp/swp00013.html

Montiel, Peter J., 1999, "Policy Responses to Volatile Capital Flows," paper presented at IMFWorld Bank-WTO conference on Capital Flows, Financial Crises, and Policies, Washington, D.C. (April).

Mussa, Michael, and others, 2000, Exchange Rate Regimes in an Increasingly Integrated World Economy, IMF Occasional Paper No. 193 (Washington: International Monetary Fund). 